\title{
El espacio escénico significación y medios
}

\section{Ana Goutman}
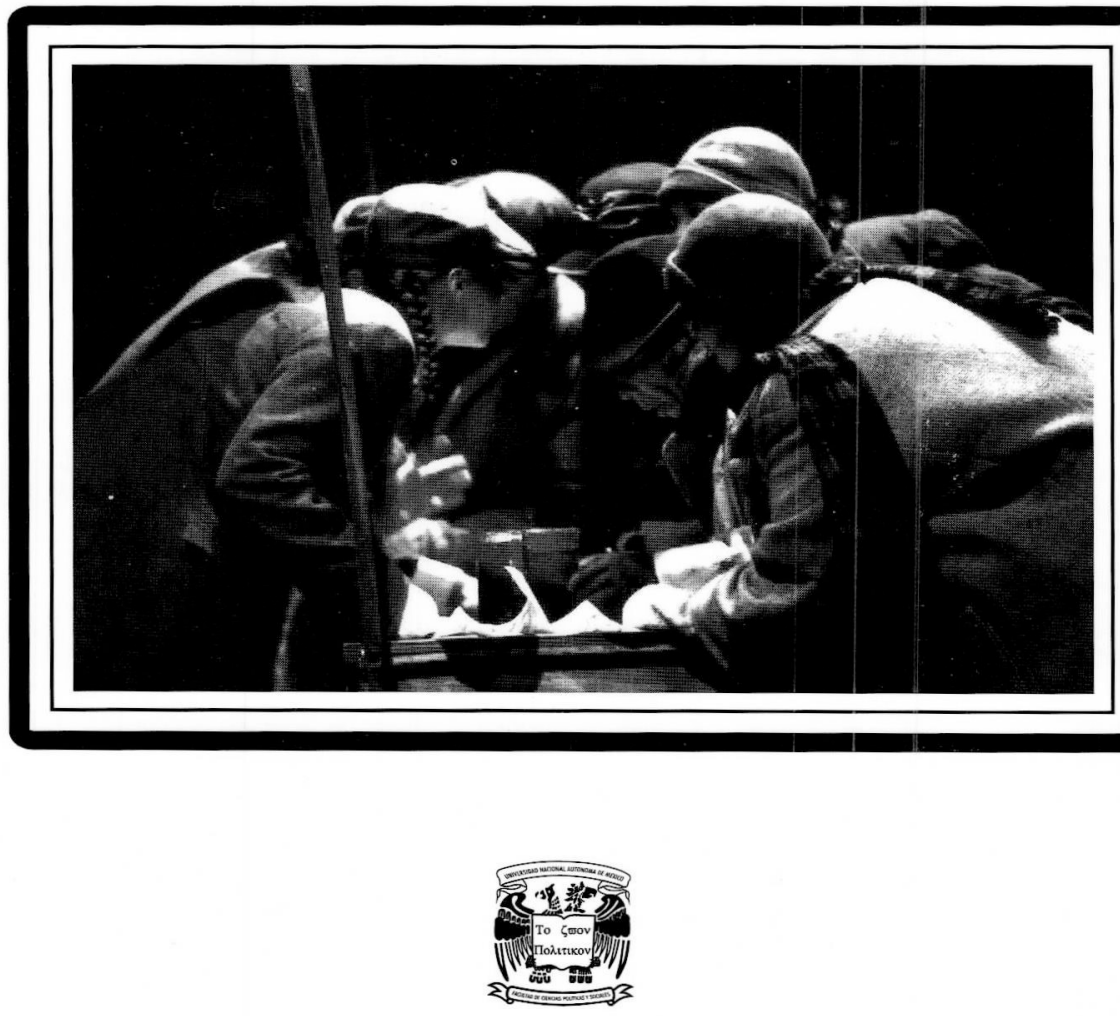

Universidad Nacional Autónoma de México

Facultad de Ciencias Politicas y Sociales 
Universidad Nacional Autónoma de México Facultad de Ciencias Politicas y Sociales

\title{
E1 Espacio Escénico \\ Significación y Medios
}

\author{
Ana Goutman
}

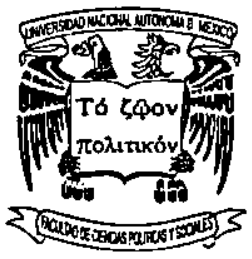


El Espacio Escénico. Significación y Medios

Derechos reservados conforme a la ley.

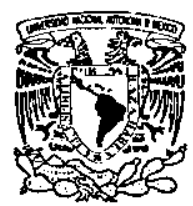

Copyright $\odot$ Universidad Nacional Autónoma de México Proyecto PAPIT IN 400199

Facultad de Ciencias Politicas y Sociales

Circuito Exterior Mario de la Cueva

Ciudad Universitaria

Mêxico, D. F. 04510

ISBN: $970-32-1180-1$

Impreso y hecho en México.

Primera ediciōn, octubre del 2003.

Cuidado de la eđición:

Domingo Cabrera Velázquez

Esta publicación no puede ser reproducida ni en todo ni en parte, ni registrada en, o transmitida por un sistema de recuperación de información, en ninguna forma ni por ningūn medio, sea mecánico, fotoquímico, electrónico, magnético, electro-óptico, por fotocopia o cualquier otro sin el permiso previo por escrito de la Universidad Nacional Autónoma de México. 


\section{Índice}

Prólogo ....................................................11

Semiótica de las culturas ...............................13

Para la semiologia o la semiótica ....................23

Los estudios semióticos sobre teatro .47

Algunas categorias de análisis

en la semiótica del espectáculo ....53

Experiencia-cuerpo-emoción ......................53

Lengua, significante, inconsciente ..............58

Surge la significación ..................................60

El discurso ............................................64

Intersubjetividad ....................................69

Transferencia .............................................69

Intersección ...............................................70

¿Qué es un momento? .............................73

La música en el espectáculo .......................76

¿Por qué no la topologia? ...........................78

Estamos en un mundo de objetos ................79

Ciencias y artes del espacio y el color............82

Realizar miradas transversales ...................88

Santa Juana de los Mataderos ........................91

Epilogando 
Los autores del "Tratado de semiótica visual", el Grupo Mu de Bélgica, acordaron investigar la imagen visual como un sistema de significación que posee una organización interna autónoma y elaborar un modelo de la manera más explicita y general posible. 


\section{Dedicatoria}

$P$ sicoanálisis y cine un libro de Christian Metz ilustra un camino diferente al que se habia recorrido hasta entonces en los estudios sobre cine.

El cine, la lingüistica y el psicoanálisis constituyeron una alianza novedosa, que legalizó la intuición que el espectáculo teatral puede desembarazarse de los cuadros de la literatura y marchar con otros aliados. 


\section{A Francisco Javier Instituto de Artes del Espectáculo Universidad de Buenos Aires}

A los estudiantes de la Universidad Nacional Autónoma de México 


\section{Prólogo}

Acometer este trabajo sobre el espacio escénico que une sala y escena, desde perspectivas diferentes que no sólo convergen, refuerzan sino lo ensanchan requiere de la consulta a los teóricos.

Quienes se ocupan de la filosofia, las artes del espacio, la comunicación, la lingüística, el psicoanálisis e incursionan lateralmente en el mundo del teatro, permitieron elaborar un entramado que sostiene esta semiótica del espectáculo.

Los creadores de espectáculos han escrito observaciones y diarios sobre su labor y validan a la vez una visión integradora de lo sabido y lo no sabido, lo sentido y lo no sentido, aqui consideramos lo que ha sido dicho sobre lo que sucede y no sucede en la sala y la escena, aquello que se abre al presente del espectador que soy yo misma.

"Semiologia de las culturas: significación del espacio escénico", el nombre que acuñó esta investigación es un tema mitad ajeno a los cánones académicos que está sin embargo prefigurado como semiologia de las culturas, pero no como significación del espacio escénico. 
El lector no debe pensar que se trata de un recetario para ver teatro o de un discurso acerca de las artes escénicas y tampoco es una lección sobre la critica teatral.

Se trata de proyectar una semiótica del espectâculo, del espectáculo teatral pero también de todo tipo de espectáculos a los que da paso la cultura.

El lugar de trabajo es la tarea docente que requiere del tiempo dedicado a la reflexión, a la presentación oportuna de algunos puntos de vista y atiende el recorrido crítico-histórico-científico que acompaña la iniciación de los estudiantes en la tarea de investigación:

Los asuntos siguen un orden que respondió a las necesidades de la descripción y el análisis, no a la interpretación de un espectáculo que se presentó en México a fines del año 2001 con la obra del dramaturgo alemán Bertold Brecht "Santa Juana de los Mataderos".

La Dirección General de Asuntos del Personal Académico de la UNAM (DGAPA) aprobó y desde luego apoyo el Proyecto PAPIT IN 400199 para la realización de este trabajo. Lo que siempre es sorpresa ante lo esperado-inesperado $y$ agradecimiento que reconforta.

Ana Goutman

Mêxico, agosto deI 2002 


\section{Semiótica de las culturas}

Aparece como un tema asaz complejo en los estudios de semiótica o de la semiosfera en la etapa actual de las investigaciones sobre el arte.

¿Es una disciplina o un proyecto intelectual que redefine la especificidad de las ciencias humanas y sociales? ¿No será una ciencia de las ciencias?, pregunta Francois Rastier.

La cultura, las culturas abarcan la totalidad de los hechos humanos, la formación de los sujetos, lo que estimula la delimitación de las mismas y da por concluido el dualismo tradicional que propuso Wilhem Dilthey con las ciencias de la naturaleza, afirma en "Arts et sciences du texte" (2001: 282).

Finalmente mantiene una vocación epistemológica,

federar las ciencias de la cultura alrededor de los conceptos del lenguaje y de la interpretación; desplazar la oposición metafisica entre sujeto $\mathrm{y}$ objeto en una distinción relativa entre la 
interpretación y el signo, restituir la complejidad radical de los textos y otras perfomances semióticas sin buscar unificarlas.

La semiótica de las culturas no ha llegado a término en varios autores y no se ha constituido en disciplina autónoma "lo que puede ser por otra parte ni deseable, ni posible". Pero es la única

que puede dar cuenta del carácter semiótico del universo humano.

Continúa el escritor que la rigurosidad de las ciencias de la cultura reside en la diversidad de las culturas que las hace moverse en tiempos y espacios diferenciados, y además cada objeto cultural dada la multiplicidad de los parámetros, impide toda experimentación, razón de su distancia con las ciencias fisicas.

La unidad de este proyecto semiológico sigue el modelo de la ciencia social que acuñó Durkheim y encuentra una posible confrontación en la obra de los estudiosos estoniano-ruso Iuri Lotman y Boris A. Uspenski.

La Semiosfera de Iuri Lotman se dedica a la semiótica de las artes y de la cultura publicada en español en el año 2000 e incluye artículos de otros autores y "Ricerche semiotiche" cuyo subtítulo es "Nuove tendenze delle scienze umane nell"URSs" publicada en italiano en 1973 con Boris Uspenski presenta la semiótica de la cultura y las aplicaciones del sistema signico. Esta última es una primera edición mundial y el fruto de la colaboración entre la 
casa editora Giulio Einaudi y un grupo de estudiosos soviéticos unidos a la organización editorial de la antigua URSS.

El tema es el método semiótico, y la extensión o progresión de una determinada esfera como objeto de investigación semiótica para mostrar una determinada lengua y los diversos modos de su realización y de su funcionamiento.

Lotman y Uspenski opinan que frecuentemente la inclusión del material nuevo en el ámbito de la investigación científica tiene un significado metodológico inmediato porque un nuevo objeto de búsqueda puede llevar a una revisiôn de los mismos métodos de búsqueda.

Por otra parte cumplida la investigación semiótica, no en la extensión, sino en la profundidad, esto es la descripción inmanente de un concreto sistema de signos nuclea en la esfera estudiada un determinado complejo de signos, ya sea para analizar las relaciones entre ellos en el texto-sintagmática- o en el sistemaparadigmática.

El grupo de participantes en el libro Ricerche semiotiche trabaja sobre los problemas signicos particulares, por cuanto es concreto el fin que persiguen, orientados hacia la prospectiva general de la construcción de una teoria sintética de la cultura. Considerada la cultura humana como una compleja jerarquia de lenguajes unifica desde el punto de vista del fin cientifico las variadas experiencias concretas. Algunos estudiosos no están interesados en la teoria abstracta de la cultura sino en una búsqueda vuelta hacia textos realmente manifiestos en la historia del pensamiento humano. 
Lo que hace evidente la brecha entre la propuesta de Francois Rastier y el grupo lotmaniano

En la Introducción a la "Ricerche..." dicen los autores:

La actual visión estructural hacia la sistematización y a la desistematización del objeto de estudio tiene la tendencia reciproca a la tensión y resistencia que determinan el funcionamiento de los sistemas signicos.

En las más variadas culturas surge periódicamente la consideración del mundo, como texto, mientras el conocimiento del mundo es igualado al análisis filológico de este texto, a la lectura, la comprensión e interpretación. Asi como el libro se presentó, en el barroco ruso, como el modelo del mundo de igual medida el alfabeto llega a ser el símbolo universal de la estructura del universo, según la cita de $\mathrm{S}$. Mathauserova.

La idea que el científico sea un lector impone naturalmente la exigencia de saber una lengua, el conocedor de la lengua se pensaba como el poliglota.

La acumulación del conocimiento en el campo concreto de las investigaciones, asume la forma de la cultura de su tiempo. Y la posibilidad de conocer se ha vuelto un asunto del metalenguaje y de problema filosoffico ha pasado a ser un problema filosófico lingüistico.

Los autores presentan, en la obra citada, estudios con los resultados y dificultades de la semiótica soviética aplicada al "teatro popular", al "comportamiento humano", al "sistema espacial de la fábula rusa" y en la "Semiosfera o semiótica de las artes y la 
cultura" estudian "el lenguaje teatral y la pintura", "semiótica de la escena", "el lugar del arte cinematográfico en el mecanismo de la cultura", "mito, nombre y cultura", "los muñecos en el sistema de la cultura" etcétera.

Rastier afirma que para Lotman la "semiótica de las culturas" deviene "culturologia", ya que reemplazó en los cursos de enseñanza rusos al materialismo dialéctico y los antagonismos de las culturas repiten lo que sucede entre las clases y concluye:

las mentalidades están formadas por la lengua y la nación, entonces un no ruso no podria comprender un texto ruso.

Lo que dice Lotman es que la investigación semiótica está estrechamente ligada no sólo a la cultura de su época, sino también a la cultura nacional y a la tradición científica, existen las culturas nacionales y en esa dimensión se inscriben los estudios que presenta en el libro a que hago referencia.

La división en escuelas es el argumento que justifica cada tradición: la americana se reúne en la obra de Sanders Peirce, tendencia próxima a la lógica simbólica y a los campos científicos limitrofes y al cîrculo lingüistico de Viena.

La división de la semiótica en semántica, sintáctica y pragmática es herencia de los estudios en investigaciones lógicas.

Hay otras orientaciones en las escuelas francesas con la obra de Levi Strauss y Roland Barthes, determinadas por la exploración semiótica de las diversas formas sociales, la antropologia, la 
etnografia, la mitologia y por otra parte los caminos que recorren los problemas de la moda, de la publicidad, etcétera.

Para Lotman y Uspenski muchos problemas que sorprenden por su novedad y se revisten de la moderna metodologia cientifica objetivan problemas de tiempo intrinseco a la cultura. Por ejemplo la idea fundamental de la semiótica de la cultura como sistema de lenguaje y de sus concretas manifestaciones como texto, sentida a menudo como novedad especifica de la semiôtica, ha sido adelantada muchas veces en el curso de la historia del saber y evidentemente es intrinseca al hombre.

¿La semiótica de las culturas remite a "una sola ciencia"? Es la pregunta inicial de Francois Rastier por la ambigüedad entre disciplina y ciencia de las ciencias. Podria Cassirer ser el autor de esa ciencia al constituir la antropologia pero en definitiva no es una ciencia o definir una variedad de ciencias afines que constituyan una ciencia.

$¿$ Ciencias diferentes para cada cultura? ¿Por qué no restituir la unidad de las ciencias en la cual estaria incluida la semiótica en el dominio científico?

Arguye Rastier que la semiótica de las culturas se instala como una concepción crítica entre la "falsa" unidad de Dilthey y la "instrumentalización" marxista. Para seguir los rastros de la semiótica se interna en la noción de génesis que se articula con la via filogenética de lo humano.

Pero no hay consenso en la sintesis de la evolución, porque se ocultaria el concepto de control genético en la categoria de causa que genera y mantiene cerrados los cambios o procesos. 
Si asi fuera no entenderiamos los cambios morfológicos, los cambios atribuidos a un azar evolutivo, negando la necesidad de las formas al orden y a las leyes de las formas. ${ }^{1}$

Lo cultural, unido a lo genético, en una génesis de las culturas es la apuesta de Francois Rastier:

La diversidad de las lenguas, la distinción de las formas simbólicas, la de las prácticas sociales, la de las artes, todos estos procesos persiguen la hominización por la humanización pero toman su autonomia según el tiempo que necesita la especie y la formación del tiempo histórico, sin "pourtant se laisser rapporter a ses rapides scancions" (2001: 284).

Lo que lleva a comunicar el interés por la epigénesis en el discurso del profesor Rastier:

se suele distinguir la filogénesis y la ontogénesis, insistiendo en que la segunda reproduce la primera, pero se olvida de la epigénesis, no en el sentido antiguo, embriológico del término, sino en su sentido reciente que se aplica a la maduración psíquica (F.R. 1991: 228).

Lícito es señalar que:

la experiencia del individuo modifica constantemente la estructura anatómica fina del

'Jean Petitot, investigador francés de la Escuela de Altos Estudios en Ciencias Sociales desarrolla en estos afios las implicaciones de la noción de forma en un artículo en la Encyclopedia Universalys. 
cerebro. Esa constatación permite reconsiderar a la luz de adquisiciones recientes de las neurociencias las teorias innatistas sobre el lenguaje.

Lo esencial redunda en que se puedan conciliar las teorias de Lorenz y las de Freud y acordar con los datos de la lingüística general acerca de las lenguas para aceptar las hipótesis sobre el carácter cultural de la percepción.

Otro es el momento de los autores de la semiótica rusa en los volúmenes que citamos.

Afirman que la teoria abstracta de la cultura no les interesa, la experiencia cientifica muestra que las construcciones culturales resultan semejantes, y la duración no es muy larga. La investigación del texto manifiesto figura en la historia del pensamiento humano. Hay que señalar que en este libro de Lotman y Uspenski no hay un tratamiento singular de esta modalidad de trabajo, pero está presente como una intención en todos los trabajos, lo que confiere sin duda unidad al planteamiento.

Es conveniente destacar, dicen los autores, que se refleja tal unidad de pensamiento en los estudios americanos en cuanto a la referencia de los signos infralingüísticos, siguiendo la filiación Locke, Peirce Morris y desarrollada por Sebeok. El lenguaje humano aparece como uno de tantos sistemas biológicos de comunicación y de significación.

La dirección francesa representada por Abraham Moles cuya obra está poco divulgada entre nosotros y la influencia de la ex Unión Soviética especialmente en la escuela de Tartu, se sitúan en el dominio de los 
signos supra-lingüisticos y el desarrollo de la semiótica de la cultura.

Jean Marie Schaeffer en el Nouveau Dictionnaire (p.185) resume que la semiótica de las culturas o la correlación funcional de los diferentes sistemas de signos -que refleja Ivanov en 1973-, ha dado lugar a estudios comparativos. Entre ellos figuran los trabajos sobre literatura, el cine escrito por Lotman o sobre el arte cuyo autor es Uspenski.

Finalmente son dos tendencias sobre la semiótica de la cultura para aquilatar una concepción que sea el testimonio de la cultura, lo que sin duda alguna se presenta como una división con las diversas variaciones nacionales fijadas en una fecha determinada.

Es posible que no se pueda ir más allá. El tema será entonces, uno más de los asuntos para explorar en las ciencias humanas y sociales al que habrá que referirse dejando de lado las pretensiones de unificar "totalidades", pero si encontrar la totalidad propia a cada coyuntura, que es una fuente de riqueza.

Una ecuánime conclusión cierra por el momento este discurso:

Una buena indagación se orienta a salir del impasse, precisando un modo propio de objetividad critica del objeto cultural y las formas de su temporalidad. Las ciencias de la cultura presentan en definitiva, "una especificidad que elude la falsa complementariedad entre las ciencias sociales y las ciencias humanas" (F.R. "La acción y el sentido"). 


\section{La semiologia o la semiótica}

Volver a Saussure para recordar que la aparición de la semiologia se debia al deseo de dar estatuto científico a la lingüistica que no pertenece al orden de las ciencias naturales, $\mathrm{ni}$ al de las ciencias históricas, sino a un orden "que si no existe debiera existir con el nombre de semiologia”, en el momento en que la noción de generalidad es la primera apuesta de pensamiento.

La autonomia de la semiótica/semiologia no discute el problema de la estabilidad o permanencia del objeto de estudio, se aproxima con el nombre de semiología a las teorias del signo de los estoicos, a la semeiotique del "Ensayo sobre el entendimiento humano" de Locke y a la obra de Ogden y Richard que en 1923 afirmaban que los enunciados literarios son pseudo proposiciones que tienen una función emotiva. Esta explicación no se defiende hoy. La concepción del signo, próxima a la del Peirce y Frege insiste en la distinción entre sentido y referente que no está en Saussure. Un signo no remite directamente a un objeto sino únicamente a través de un significado que selecciona ciertos presupuestos pertinentes para 
la relación vista a la que remite, afirma Oswald Ducrot en el "Nouveau Dictionnaire" (p.217).

¿Es más fácil ahora determinar el objeto de la semiologia?

La variedad de teorizaciones, las numerosas y consistentes conceptualizaciones requieren atender la relativa incompatibilidad entre ellas tan a menudo medida y comentada. Porque la exigencia de una ciencia fundamental y totalizante, por vocación, susceptible de rendir cuenta a la vez del campo cultural se sostiene en la diversidad de sus aspectos, los signos y en la homogeneidad de sus manifestaciones, las del signo.

El análisis lleva a desmembrar las nervaduras de esta propuesta y uno tiende a averiguar para qué se toma uno tal trabajo, y eso a su vez exige saber si el objeto permite esa fragmentación. Como anuncié, se trata de la semiologia del espectáculo y parece pertinente introducir esta manera de conocer que se padece frente a un espectáculo.

Hasta la fecha en la semiologia del teatro se han adoptado los lineamientos consolidados en las lides literarias y con el condimento de una llamada partitura que serviria para poner esa literatura en escena. Partitura tiene resonancia musicaly el sujeto que la ejecuta pretende unificar los elementos para crear un mundo que sino no existiria.

Pero seguimos deudores de la escritura que es justamente donde los estudiosos del tema marcan los limites de un espectáculo.

Estas son las razones que me impulsaron a traer los sabores de las semiologias con las que se podrá construir un enfoque analítico, previo conocimiento 
de ese todo al que asistimos, elaboramos y disfrutamos que es un espectáculo.

Lo que resulta curioso es que quienes trabajan en estos temas del teatro y otros espectáculos integran de manera oculta las fuentes que no están en la escritura y dedican monografias a la música, los gestos, la actuación, el actor, la actriz, los colores, el espacio, la visión, en fin toda suerte de colaboradores que residen en el espectáculo y de los que no se puede prescindir.

Mi pregunta es ¿por qué no tomarlos en cuenta en una investigación desde el inicio? ¿Hasta cuándo seguir privilegiando la dramaturgia y codificarla como la propia del actor y de cada uno de esos elementos que integran el teatro? Es la via de una semiologia/ semiótica la que lleva a unificar los elementos citados al tiempo que centra en el sujeto espectador la creación de cada instante de una representación.

Por supuesto fue la intuición de que esto es posible, lo que me llevô a recorrer los "oscuros" pasillos de la descripción semiótica y de esto voy a dejar constancia.

La historia de la semiótica/semiologia ha sido presentada a veces como una relación entre signo/ser, semiologia/ontologia que cuestiona el valor de la idea de semiologia/semiótica porque según Luis Prieto, Buyssens, Algirdas Greimas, Roland Barthes es una modificación de la lingüística estructural, para cumplir la misión que le espera. ¿Cuál es? Ser modelo de cientificidad en un ideal positivo de la ciencia, según dos investigadores J.-L Chiss y Christian Puech. Parece que la propuesta de Saussure es la que se mantiene. 
Chiss y Puech afirman que la semiótica no es una disciplina asi como se entiende la noción por la imposibilidad de cerrar la productividad indefinida del proceso semiótico en un dominio estricto y conciliar la exigencia de totalización y la de cientificidad.

Reciprocamente la idea de semiologia proporciona a la lingüistica estructural el horizonte en el que ella puede atender su desarrollo. Ya sea por el uso de procedimientos formales con los cuales el punto de vista semiológico/semiótico reconduce al lingüista al signo, única unidad positiva, segũn Saussure.

Entonces la semántica aparece como ciencia bisagra cuyo estatuto dirige las relaciones entre la lingüistica y la semiología y recuerda la paradoja de lo arbitrario del signo que se refiere a la no relación entre significado y significante, sino entre signo y referente.

El concepto o la noción de semiosis lleva en si una historia a medias implicita pues hay una diversidad del producto semiótico que instaura una unidad de operación semiotizante. Pero no se dice si la semiosis se puede atribuir a un sujeto o se debe sobretodo imputar a un campo anónimo, una suerte de agente operador $\sin$ nombre, ni rostro, ni ninguna otra materialidad que la de la operatividad sin limites (Dicc. Greimas).

Louis Hjelmslev llama semiosis a una operación de presuposición reciproca entre la forma de la expresión, y la del contenido, lo que atrae la complejidad de la referencia del autor a la duplicación que ha' presentado cuando retoma las nociones de significante o expresión y significado o contenido en las que reconoce una forma y un contenido. 
Por lo cual la forma de la expresión es la ley que rige la forma del contenido.

Hay una serie de paradojas o dificultades que Chiss y Puech señalan para ilustrar cuestiones internas y no debatidas que llevan a preguntar si la idea de semiología no es, desde la orientación propiamente lingüística, sobre todo un punto de contradicción $o$ al menos de tensión y de encubrimiento de tensiones.

Por ejemplo: ¿Cuál será la suerte del sentido? ¿Cuál la orientación semiológica del meta-discurso que aspira a romper lo que funda? La finalidad seria proponer una declaración de la autonomia de la semiótica. Es una hipótesis que sitúa a la semiologia más allá del proyecto y de la episteme semiológica a la que determina el sentido.

Para acordar alguna respuesta a estas preguntas, es conveniente dar algún paso atrás hacia la historia. Chiss y Puech atienden tres asuntos que preocupan al investigador.

¿Qué distingue, según la historia, la idea de una ciencia general de los signos articulada con la concepción de la lingüistica de la lengua de una Filosofia de la Cultura que expuso Cassirer o más tarde Merleau Ponty cuando no podia ser negada la existencia de una ciencia del lenguaje?

¿Qué es un proyecto semiológico que réclama positividad, autonomia y cómo se piensa en relación con la lingũistica y su autonomia disciplinaria en función de qué representación de ciencia? 
Finalmente:

¿qué es la episteme semiológica y en qué medida es una inauguración. Qué tipos de relaciones mantiene con lo que ella pretende o quiere romper (filosofia, lingüistica, filologia)?

Siguiendo el articulo publicado en 1992, indica que los tres asuntos sugieren dos enfoques. Uno concierne la emergencia misma de la idea de una ciencia general de los signos y su contenido del que la lingüistica constituiría a la vez el "patrón" y el modelo. El segundo concierne a la reorganización de las disciplinas ante la aparición de un campo semiológico y el lugar ocupado por la lingüística su forma y su problemática, en ese campo.

A ciertas luces, es una reiteración que se presenta siguiendo cierto esquema circular de búsqueda, que se vislumbra en el articulo citado. Por esta razón consulté un libro "Pour une histoire de la logique" de Claude Imbert, confirmando que:

las paradojas o dificultades son tanto o más inescrutables que la investigación que falta por hacer. Si todos los sistemas terminan en paradojas, no prueba nada, sino que todos, en la misma lengua natural están sometidos a presiones semánticas y sintácticas constitutivas.

Las presiones de una totalidad o suma histórica, los limites temporales que impone, pueden acreditar la hipótesis de que las variaciones son tolerables desde que son acumulativas. La idea de acumulación 
confirma la existencia de lo que puede ser visitado o revisitado y condiciona el conocimiento adquirido.

El propósito de analizar la mayor cantidad posible de rasgos originales favorecia o demandaba un uso puntual de la transcripción formal utilizada a la manera de un test. Es decir lo que puede "repetirse" en el sentido de reunir datos que se resignifican.

Claude Imbert, a partir de la historia de la lógica concluye que una actividad filosófica liberada de las operaciones oscuras del sentido común, consciente de sus simbolismos, da sentido a los cambios en el entendimiento, que redundan en una aportación filosófica esencial y constante contra los métodos que suponen regir todas las maneras del conocimiento. Los cambios en el entendimiento afirman el tema de la actual lógica que también atrae al psicoanálisis.

Los conflictos filosóficos (265) como la oposición inmemorial entre el empirismo y el a priori perdieron su idea de contraste tajante. Se puede discutir sobre lo adquirido y lo innato, no se puede impedir que los argumentos se ubiquen aparte, que se opongan en dos modos de desarrollo, y dos modos de transformación, según sean definidos en el seno de una sintaxis conceptual solidaria de una lengua natural o inmediatamente implicados por una sintaxis funcional. Podria ser que si los psicoanalistas consideran hoy que es una tarea la reforma del entendimiento, renuncien a investigar una arqueologia inmanente, afirma el autor.

Esta historia para Claude Imbert "se trama en Port Royal, D' Alembert, Wittgenstein, Cavaillés y Merleau Ponty" (texto de la portada). Porque lo que da sentido a las reformas del entendimiento, es una 
operación filosófica esencial y constante contra los métodos que regian todas las maneras del conocer.

Nuestros conocimientos tienen diversidad de soportes, inscritos sobre un pergamino de operaciones inconscientes que preceden a toda epistemologia.

La reflexión y el conocimiento corren parejos obstáculos, aunque puede suponerse que una abre el camino al otro, sucede que se intercalan $\mathrm{y}$ se interpenetran, a la vez que se suceden o siguen.

Estas conclusiones son el instrumento para ingresar a la revisión de propuestas semióticas. Vamos a ver lo que se ha dicho y lo que se piensa en torno a la semiótica y cuestionar algunas ideas de Sebeok, Hjelmslev y Barthes. Cuestionar es una manera de leer y confrontar el análisis del objeto que es el espacio escénico.

La más antigua de las fuentes notables es la semiótica médica o clínica cuya cabeza visible es Hipócrates (460-377 a.c.) y la mayoría de los filósofos griegos se han ocupado de la teoria médica y de la herencia de Hipócrates. La razón consiste en la práctica arcaica sobre la enfermedad y sus causas pues cambió la atención y la puso en el hombre enfermo y sus sintomas, no en el fenómeno general, por ejemplo atrae la reflexión teórica sobre la descripción del rostro de un paciente.

Dice Sebeok que si Hipócrates fue el padre de la semiótica, el profeta a seis siglos de distancia fue Galeno (130 a.c.) que afirmaba que "el mejor médico 
es filósofo". La disciplina médica que atiende la sintomatologia en Occidente se conoce como semiótica y los derivados de sema.

No hay variantes con las observaciones actualmente canónicas, pues la teoria más amplia de la semiótica de la enfermedad parte de una teoría del signo en la medicina y conduce a una afirmación que la enfermedad más peligrosa es la que está en la cabeza, es un problema de mala comunicación. La cêlula y su tejido responden a una falsa información o interpretan de un modo incorrecto estimulos ambientales a los que hiperreacciona.

Roland Barthes refuerza esta idea porque afirma que la medicina de hoy es verdaderamente semiótica, pues la semiótica médica es uno de los hilos mâs estrechamente tejidos en la trama de la teoria del signo y el mâs antiguo. Mientras generaciones de filósofos $\mathrm{y}$ algunos lingüistas estaban prefigurando una vaga ciencia del signo, que según Saussure no existia, dedicando alguna atención al sistema de signos diferente del especifico del hombre, un diverso grupo de estudiosos trabajaba para desarrollar o redefinir la etologia, un campo que Sebeok ha descrito como "algo más que un caso particular de la semiótica diacrónica”.

La biologia precisa la relación entre una situación dinámica global que es el significado y la morfologia local en la que se manifiesta como significante, lo que determina una significación que es la prueba de una práctica semiológica.

La significación concierne al problema de la distinción entre organismos vivos y formas inertes, entre hombre y animal y entre animal y planta y el 
problema del origen del lenguaje y de la estructura sintáctica. Tiene una nota de ritualización.

Algunos soportes empiricos son relativos al dominio de la semiosis en el universo viviente, dice Sebeok, porque una plena comprensión de la dinámica de la semiosis pude ser en última instancia la definición de vida.

En los estudios sobre Historia de la semiótica se encuentran perfiles afines a los que señala Sebeok y es posible integrar la semiótica médica a la tarea de la semiótica general del signo y de los aspectos de esta doctrina en el aporte capital de la etologia. Las relaciones entre la semiótica, la etologia que reseña Rastier y la topologia que atiende las construcciones en el espacio y actualiza la geometría conocida, son las posibilidades de encauzar la semiologia en campos definidos.

Hasta ahora la historia de la investigación semiótica muestra en conjunto una oscilación entre dos interpretaciones aparentemente antitéticas: la más extensiva es la semiótica considerada como intrinseca a la naturaleza del lenguaje y de la cultura. La interpretación más restrictiva es vista de modo explicito o menos implícito como vinculada estrechamente al lenguaje, lo que representa al hombre.

Los temas de la semiótica que desarrolla Sebeok se refieren al área de estudio de la comunicación humana no verbal, donde dos grupos se disputan la visión "universalista" $\mathrm{y}$ "relativista" : una que observa el rostro, no se limita a él y retoman el tratamiento clásico que mira al hombre como el animal según el argumento de Darwin. 
La posición universalista afirma que el movimiento muscular del rostro está asociado por via hereditaria con la misma emoción y asi lo sostiene la etología (1970) según algunos eminentes psicólogos.

Los "relativistas" ven en la expresión facial que no es completamente innata, la afinidad con el lenguaje que se acerca al interior de cada cultura (Ekmann 1972 y defendida por los antropólogos de la linea de Birdwhistell). Los estudios posteriores afirman que hay que abandonar la idea de la expresión facial que constituye un lenguaje en que los músculos faciales tienen un significado diferente en cada cultura porque en último anälisis los đatos prueban la existencia de expresiones universales, analizables con los métodos ordinarios de la ciencia natural.

Para Sebeok, quien persiste en esta linea de exploración, la determinación de una expresión pancultural implica sin embargo la existencia de diferencias culturales y proporciona un cierto número de indicaciones ya sea sobre el origen o sobre el esquema en el que esta manifestación puede ser registrada y descrita a travês de los métodos complementarios de la ciencia social.

Tomás Sebeok expone las distinciones que presuponen en principio un sistema antroposemiótico, propio de la especie como el lenguaje y aporta lo que llama los constructos más complejos que requieren para su composición una infraestructura verbal del sistema zoosemiótico. Son dos códigos que ubica en la base de la comunicación humana y animal. 
Los sistemas coexisten, contrariamente a la creencia común, que "en la evolución del hombre el lenguaje habia sustituido los sistemas torpes propios de los animales." Creencias cuyas razones expuso Bateson y son falsas dice Sebeok.

La evolución humana presenta las dos modalidades propias a la interacciôn cotidiana aún como refinadas expresiones del arte igualmente complejas, independientes y diversamente funcionales siempre en relación reciproca de sostén y de integración. La sustitución o reemplazo es lo que no se ha comprobado, no es más que especulación.

La risa y la sonrisa se reconoce en el hombre y hay imágenes de esculturas primitivas que lo reflejan, pero según algunos estudios es evidente el grado de estereotipo reflejo y de automatismo. Aplicando un método comparativo, Sebeok, siguiendo a Hoff opina que (Cita de Sebeok, 1971, parte II) esta pareja de signos metacomunicativos se inserta perfectamente en la escala filética, porque ambos se ligan a las manifestaciones de mamiferos primitivos.

La homología determina el carácter zoosemiótico de la risa y la sonrisa según una gradual ritualización, modelización y amalgama final en torno a dos polos en una serie que va de la reacción genérica amistosa -sonrisa- a la alegria-risa-caracterizada en el hombre por los adornos morfológicos o ruidos.

Ambas interpretaciones de la semiosis, se originan en Francia una de Barthes deriva de Saussure y la otra representada por René Thom deriva de Peirce.

Dice Sebeok en el fasciculo que comentamos que la observación de Thom "sólo aquéllos que saben escuchar la respuesta de la naturaleza llegarán luego 
a dialogar con ella y a manejar una nueva lengua”, toma la esencia del proyecto semiótico y lo lleva a un nivel donde nadie antes se habia aventurado tari audazmente (Cita de Sebeok, 1973:106).

Un personaje de la investigación semiótica es el barón Jacob von Uexküll que contribuyó a sentar las bases teóricas de la moderna etologia y fue de los más destacados cripto semióticos de la primera mitad del siglo $\mathrm{XX}$, porque indagó la capacidad sensorial de los animales y el modo en que el mundo se configura en su mente. Según Uexküll, el animal sólo puede responder a una pequeña parte del espectro de la percepción porque su organismo sensorial opera como una especie de filtro de los vehículos signicos. $Y$ sólo es significante para un animal el objeto que tiene significación para su vida.

Adquirido el significado, el vehiculo se transforma en portador de sentido para el intérprete que, según Peirce, está autorizado a proporcionar una parte del significado.

Sebeok ha estudiado este campo de trabajo semiótico y sin duda ha estimulado una corriente de zoosemióticos que continúan sus pasos. La obra de Thomas Sebeok sienta bases para quienes creen que la semiótica está lejos de ocupar sólo un lugar en la cultura y se inscribe en la preocupación de percibir lo que una sustancia significa, fatalmente recurre al recorte de la lengua, el mundo de los significados no es otro que el del lenguaje. Con lo cual recorre la naturaleza, las formas y la vida.

Descubre el proceso de elaboración de disciplinas conexas que desdoblan el campo lingüistico en el etnosemiótico por el análisis de rituales y ceremonias, 
el psico semiótico por el estudio de Hjelmslev y también la socio semiótica de las connotaciones sociales.

A partir del postulado fundamental de toda semiótica, la presuposición reciproca de significante y significado, la empresa totalizadora no sabe fijarse limites a priori que residen en la teoria general de la narratividad y de la discursividad, de la intersubjetividad, del sujeto, del mundo y de la transformación del mundo. La semiótica, concluye el investigador, configura todos los fenomenos que tratan las ciencias humanas y sociales.

Otra de las concepciones de la semiótica que consulté y que atraviesan la historia de las ideas es obra de Louis Hjelmslev, cuya proximidad a la semiótica es determinante, dedicó su obra a una de las más precisas y proyectivas investigaciones, y su novedad epistemológica interesa al conjunto de las ciencias sociales.

A partir de la propuesta saussureana abre los caminos que estaban dibujados y avanza hacia la finalidad de abandonar el privilegio dado al signo. ¿Cómo lo logra? Recurre al origen fonológico que señalaron los miembros de la Escuela de Praga donde reside la matriz de la lengua. Las unidades fonológicas más pequeñas que el signo, los fonemas, reemplazan al signo y comienzan a funcionar las leyes combinatorias. El mismo método aplicado al contenido o significado permite distinguir tres elementos por lo menos: semántica o semas, unidades semänticas y fönicas.

Conviene reconocer que las leyes combinatorias 
de los fonemas de una lengua y la de los semas no se corresponden. Ambos planos no se confirman o no están de acuerdo. Pero no se niega el isomorfismo ya que se toman en cuenta los dos lados con el mismo tipo de relaciones combinatorias.

Hjelmslev dice en 1939 que "apoyăndose en el principio arbitrario del signo la forma lingüistica es independiente de la sustancia en la cual ella se manifiesta y que la forma no puede ser reconocida y definida sino haciendo abstracción de la sustancia y ubicándose en el terreno de la función" (p.67).

Se trata de una descripción y clasificación puramente funcional de los elementos que debe operarse de manera deductiva (p. 68). El lugar que ocupa el principio arbitrario del signo es lo que orienta la independencia y reconoce la función.

Las leyes de conmutación son la prueba que utilizó la fonologia y se repite la idea de que es funcional e independiente de la sustancia particular, porque las unidades de la expresión no se definen por criterios fonológicos, asi como las unidades del contenido no se definen por criterios de la semántica.

Es un método empirico que se opone al apriorismo de la fonética clásica y de la filosofia de procedimiento inductivo y debe ser reemplazado por un procedimiento estrictamente deductivo. Porque la sustancia se reconoce a través de la forma, no tiene otro modo de existencia, sin ella es una masa amorfa. Partir de unidades desmembradas, es erróneo, no hay elementos separados o solitarios que articulen una idea.

Materia, sustancia y forma se aplican a la expresión y al contenido, lo que Saussure llamaba significante y significado, que señala los niveles 
lingüisticos fundamentales.

Cuando Hjelmslev dice "forma de contenido" es poco inteligible, pero observamos que distingue 10 formal porque al atender la propuesta del formalismo que no implica un rechazo a considerar el sentido, tiene la voluntad de hacer una descripción formal de los hechos de significación.

Hjelmslev aprueba la intención que guia la oposición saussureana de la sustancia y utiliza el método fonológico de la conmutación al que somete a la misma crítica que hace al principio de opositividad pues considera que la conmutación sirve solamente para distinguir los elementos lingüisticos inferiores al-signo, pero no permite decir lo que son (O. Ducrot. Nouveau Dictionnaire).

Mientras el fonólogo define cada fonema según el principio de opositividad por lo que lo distingue de los otros fonemas, Hjelmslev no define los elementos más que por sus relaciones combinatorias. Para marcar bien esa diferencia con la fonologia ha creado una terminologia propia.

Cuando se refiere a las unidades lingüisticas, no fonológicas, introduce un recorte o división o desglose al perfil original en el mundo del sonido y de la significación. Pero es necesario que las unidades sean algo diferentes que ese recorte, diferentes a las regiones de sentido y de sonoridad, para que pueda proyectarse en la realidad es necesario que existan independientemente de ésta y entonces nuestra incursión por la semiologia adquiere rasgos de un propósito abarcador, inclusivo, pero penetrado por el propósito de ensanchar ese campo (O. Ducrot. Nouveau Dictionnaire).

¿Cómo define el lingüista las unidades si se le 
impone hacer abstracción de su relación tanto intelectual como sensible? Con seguridad no recurriendo al principio de opositividad, recurso que Ducrot llama la primera concepción de Saussure, porque este principio conduce finalmente a caracterizar la unidad de manera positiva, e interesa que se la reduzca a la diferencia con otras.

La apuesta de Hjelmslev es desarrollar al extremo otra concepción saussureana, la segunda, según la cual la unidad puramente negativa y relacional no puede definirse en si misma. Lo importante es el hecho que sea diferente de otras pero solamente por las relaciones que ligan unas unidades a otras de la lengua y a si misma.

En definitiva no se pide a los simbolos de un sistema formal más que sean distintos los unos de los otros y ligados entre ellos por leyes de funcionamiento explicitas. Se hace abstracción pues a la vez de su significación y de su manifestación perceptible. La relación es el modo de conocer lo diferente, de lo que se trata no sólo en la lengua sino en todo tipo de relaciones en la ciencia. Lo que define lo formal, es lo que puede ser conocido.

Como decia ya Saussure la lengua es forma no sustancia, no hay referencia ontológica y esto es asi porque sus unidades deben definirse por las reglas según las cuales se las puede combinar por el juego que autorizan.

Lo dice la idea que una lengua puede permanecer fundamentalmente idéntica à si misma cuando se modifican las significaciones que ella expresa y los medios materiales de los que se sirve, cuando se transforma una lengua hablada en lengua escrita, 
gestual, dibujada en un sistema de signos como bandera o pabellón (Ducrot. Nouveau Dictionnaire: p.37).

Saussure indicó en la lengua dos niveles, la sustancia saussureana es decir la realidad semántica o fónica independiente de todo uso lingüistico. Hjelmslev la llama materia y en la traducción francesa se habla de sentido. La forma que se destaca en la primera concepción de Saussure con la idea de configuración o recorte Hjelmslev la llama sustancia y reserva el término de forma para la red relacional que define las unidades, lo que es igual a "forme" en palabras de Saussure.

La novedad del vocabulario que autoriza Louis Hjelmslev destaca el concepto de glosemática que sirve al autor para dar un rol fundamental a la forma desprovista de toda realidad semántica o fónica y relega a segundo plano la función, especialmente el rol de la lengua en la comunicación, ya que ese rol es pareja de la noción de sustancia. Para ligar los tres niveles de la glosemática utiliza la noción de manifestación: la sustancia es la manifestación de la forma en la materia.

Si se conduce de manera abstracta el estudio de las lenguas llega como esperaba Saussure a un estudio general de los lenguajes lo que en el "Curso" denomina semiologia.

Este esfuerzo de abstracción es finalmente un modelo para los lingüistas que ponen al orden lingüistico como irreductible y admiten un primado de la lengua en el sentido en que Merleau Ponty hablaba de un primado de la percepción. No habia nada antes. Para describir la lengua hay que tener 
en cuenta las relaciones interlingüisticas entre los tèrminos que se definen a si mismos sólo por las relaciones que los unen (Ducrot. Nouveau Dictionnaire: p.40).

En definitiva la lingüística no es más que una región de la teoria del lenguaje que realiza un proyecto saussureano de una semiótica general que Bogatyrev habia iniciado en la etnografia y Mukarovsky en la estética.

El concepto de sustancia y el de forma y la oposición entre ellos es una presencia constante en la obra de Hjelmslev y distingue la sustancia no formada semióticamente o materia, de la sustancia semióticamente formada que puede y debe pertenecer a los objetos y la reenvia a la ontologia. Es precisamente la sustancia semióticamente formada la que constituye el punto de contacto entre la lingüistica y las otras disciplinas.

Jean Laplanche afirma que la unidad, según Saussure, corresponde a los cuatro términos de Hjelmslev, en los que interviene la forma. Son los únicos que pueden constituir el objeto de la lingüística estructural según el enunciado de Saussure que la lengua no es sustancia sino forma.

Resumiendo para despejar confusiones, sólo puede estudiarse la forma, y se puede poner en relación la forma de un significante que especifica el valor con la forma de un significado que Saussure llamaba el concepto o imagen mental.

La lingüistica no puede ocuparse de los fenómenos materiales puramente físicos que constituyen la sustancia de la expresión. Un mismo lenguaje puede ser estudiado tanto en la transcripción oral cuya 
materia sea sonora o escrita o en los sistemas de oposición, la "forma" de la expresión permanece la misma.

Por otra parte la dirección intencional alude corrientemente al referente (no se puede tomar en consideraciōn).

Lo que Lacan llama primado del significante es finalmente después de Saussure el primado de la forma (Lacan p.132).

Hjelmslev propone una fundación formal de la lingüistica que pueda abarcar otras ciencias humanas. La teoria del lenguaje pasa de las letras a las matemáticas por la lingüistica, por ello la teoría del lenguaje es la unificadora de las ciencias.

La noción de interpretación hermenéutica que estudia Francois Rastier no le es útil a Hjelmslev porque lo que decide si hay signo no es el hecho de ser interpretado (1971 p.40). Esta posición de Hjelmslev parece ligada al estatuto inescencial de la semántica.

La distinción citada entre forma y sustancia radica en el análisis y la interpretación es producto de la sintesis. En los estudios de lógica no se habla de interpretación porque está excluida del sistema.

También Roland Barthes trabaja por esas fechas con la idea de una semiologia que no considera una causa para deferider, ni una ciencia, ni una disciplina, ni una escuela, es un movimiento con el cual se identifica al que se le puede dar el nombre de significante.

Considera que siendo una aventura personal ser semiólogo él estã entre los semiólogos por solidaridad, 
pero no subjetiva porque el sujeto se desplaza en tres momentos. El primero parte de la admiración, cuando puede ubicar sus estudios de los mitos pequeño burgueses, que fueron solamente una proclama en el área de los estudios cientificos o sea el área del análisis fino de los procesos de sentido. Los mitos le mostraron que la burguesia convirtió su cultura histórica de clase en naturaleza universal, y la semiologia aparecia como el método fundamental de la critica ideológica (1985: p. 11). Elaboró Barthes un instrumento de análisis y el estudio del sentido adquiria un alcance político.

Un segundo momento fue el de la ciencia o al menos el de la cientificidad. Barthes trabajó desde 1957 a 1963 para conducir el análisis semiológico de un objeto altamente significante "la ropa de moda". La finalidad fue restituir minuciosamente la gramática de una lengua conocida pero que aún no habia sido analizada.

A continuación la redacción de los Elementos de semiologia le sirvió para recuperar el momento de sus amigos Greimas y Eco y las confluencias con Jakobson y Benveniste y los investigadores más jóvenes Bremond y Metz.

Barthes queria fundar una sistemática, más que una semiologia, queria entrar por el placer del significante en el texto (1985: p.12).

El texto representa un tercer momento, en el que los discursos se entretejian alrededor de él y desplazaban los prejuicios, inquietaban las evidencias y proponian nuevos conceptos.

La importancia que da al texto, lo distingue de la obra literaria, porque no es un producto estético, sino 
una práctica significante. No es una estructura sino una estructuración, no es un objeto sino un trabajo, un juego, no es un conjunto cerrado de signos dotado de un sentido que trataria de reencontrar, es un volumen de marcas que se van desplazando.

Barthes insiste que el texto no es una significación sino un significante en la acepción semiótica y psicoanalitica de este término.

La semiologia "cuestiona su propio discurso", por eso no es una ciencia y el problema que se plantea es alcanzar a no reducir el texto a un significado que sea histórico, económico, folklórico, pero mantener su significación abierta.

Barthes se aproxima a la via del psicoanálisis para preguntar acerca del lugar desde el que se habla, pregunta sin la cual toda ciencia y toda critica ideológica son irrisorias. Para la semiologia no existe una extraterritorialidad del sujeto, aunque fuera sabio. No hay modo de olvidarse del sujeto en la semiótica.

Cuando Barthes señala al significante, que de manera corriente se llama signo, el tema de las culturas se refuerza con una singularidad irrepetible. Pero hay que ver funcionar esas culturas a partir de lo que cada uno de nosotros traduce.

Las ideas de Barthes, por la via de la discusión ideológica complementan las conclusiones de Louis Hjelmslev que parte de las exigencias de la lengua y lo llevan sin duda a pensar en un lenguaje. Leyes, normas, modelos están entre las novedades que presentan al sujeto una nueva realidad de análisis.

No es una interpretación porque lo que tenemos es un conjunto de significantes, es decir lo que 
llamamos texto, y ese texto nos llega, se traduce cuando se encuentra con el texto inconsciente del sujeto y adquiere sentido. 


\section{Los estudios semióticos sobre teatro}

Parten en su mayoria de la propuesta de la literatura dramática y curiosamente se le van agregando aditamentos o etapas que el estudioso del hecho teatral considera componentes estimables que complementan la conocida semiótica de los signos.

Quiero decir que incluyen los textos que ya no son el del autor dramático sino el que confecciona el director, el actor, la actriz, el escenógrafo y que son relevos de la escritura en la escena.

Algirdas Greimas ha diseñado un cuadro de los actantes o personajes que configuran y construyen la dramaturgia que existe en tanto cada uno de esos elementos se interrelacionan.

En la revista Degrés especializada en temas de estudios teatrales desde los más apegados a la letra del teatro clásico a los que son deudores de la psicologia, la antropologia la educación Eugenio Barba ha difundido sus reflexiones sobre la antropologia teatral. Desde los años setenta a los noventa fue el gurú de los grúpos de teatro latinoamericano y europeo por distintos medios. 
Las enseñanzas de Barba figuran en libros que leídos hoy a la luz de la crítica teatral denuncian los sintomas de una visión reducida del espectáculo y la creación.

La emoción contrariamente a la opinión ingenua que la define como una fuerza que se apodera de una persona y lo subyuga, la emoción es en realidad un conjunto de reacciones a un estímulo (p.a.6).

Los estudios actuales han abandonado esta nueva ingenuidad de estimulo y respuesta en cadena que Barba considera una actualización del trabajo del actor. Estudiar al actor dentro de las ciencias particulares, lo separa de su ámbito natural. La generalización de las ciencias no es la escena donde queda librado a sus emociones.

La acción fija del actor es la más pequeña acción perceptible y que se reconoce por el hecho que aún si tú cumples una acción microscópica la tonicidad entera del cuerpo se modifica.

Creo en un método negativo para hacer surgir la dimensión interior, no impedir que la interioridad se desarrolle y el secreto es una cosa que se puede aprender a condición de actuar como sino se pudiera aprender.

Estas indicaciones al actor fuera del área de la creación resultan un tanto esotéricas para la enseñanza. Que por otra parte el actor realiza en su práctica cotidiana de ejercicios, improvisaciones y repeticiones lejos del intento de una receta. 
Otros estudios realizados por maestros universitarios franceses como Tadeusz Kowzan, Anne Übersfeld, Michel Corvin, Patrice Pavis, los más conocidos entre nosotros están dirigidos a la "puesta en escena" moderna o "posmoderna", a los actos de habla y a las posibles dramaturgias del actor y la actriz.

Estos breves señalamientos no soslayan la continuidad de los estudios semióticos, mi propósito es solamente indicar que hacia falta dar un giro en la actitud de conocimiento.

La variedad de miradas sobre la escena no muestran un enfoque totalizador desde lo teórico sino un tenaz reconocimiento de cargas semánticas.

El ámbito de la dramaturgia, una de los más extensos entre las investigaciones de teatro, funciona de manera sistemática y desintegra el fenómeno teatral que es el espectáculo, por su afán de fidelidad al escenario.

La distancia que existe de los estudios sobre las dramaturgias al anâlisis del espectáculo que el espectador comparte y en el que participa es la que existe entre las investigaciones conocidas de la semiótica tradicional y la que tiene que ver con este. proyecto de análisis de la significación del espacio escénico.

Los dramaturgos han escrito sobre sus creaciones como Daniel Veronese, Peter Broook, Sanchis Sinisterra, Julia Varley, Jean Lecoq y otros más trabajan con los fantasmas de sus propias historias, no en lugares ideales porque son desconocidos, sino ideales porque se pretenden realizar.

Los fenómenos artisticos con estructura dada en 
los que el espectador participa y mimetiza un significado se distinguen de aquellos en los que las expectativas del espectador estân frustradas porque renuncia a toda representación realista y se permite la aventura de creer en la función y el valor que cumplen el teatro, la danza, la opera, las artes del espacio.

¿Cuál es esa función? No al mensaje, no a la moraleja. Si no se sale a decir algo ¿para qué?

Pero ¿cuándo? En el absoluto presente.

En el teatro de Antonin Artaud como teatro de la crueldad no se puede aprehender un ruego, o la felicidad o el dolor o el amor porque todo está desprovisto de lo que conocemos y temblamos ante lo desconocido.

Estas notas describen la experiencia del espectador que no está prevenido y que atiende los asuntos de la emoción, el inconsciente, la historia personal. En ese momento no hay que buscar la continuidad, ni el mestizaje y se invierte la mirada que acostumbramos a dirigir. Descentralizar la mirada, la actitud de la mirada, no la idea fisica de mirar. Porque aparece una vibración o una palpitación que supone un momento de tensión de la acción y aviva el interés. Es el permanente descubrimiento de la subjetividad que tiene que ver con la construcción de sentido como en el plano de los procedimientos.

Nuestra percepción es limitada y sin embargo no basta una idea para que sirva de sostén, porque llegamos a los límites de lo que se ha dicho y en ese lugar el espectador se encuentra con lo obsceno, to 
torpe. Con lo que debe ser desplazado fuera de la escena que no debe ser representado a la vista del espectador porque sigue siendo lo intimo, lo violento, lo guardado, lo propio, lo que nació para no ser mostrado porque ha cambiado la rutina.

Sucede la primera vez, es como una sorpresa. Esa primera vez nos deslumbra y despierta los sentidos. Siempre ocurre ante un espectáculo porque es lo inesperado, o más bien cuando es lo inesperado como la cualidad determinante de un acto creativo.

Daniel Veronese se refiere a "estar fuera de" la cultura la que ya no se expresa más que en el teatro, porque es su lugar. El destino de la rebelión no está en un lugar conocido, desafia.

La "experiencia del goce estético" y la conciencia de teatralidad, multiplicidad de poéticas dramáticas expresan un acontecimiento que está en el lenguaje que denuncia todo efecto de realidad. 


\section{Algunas categorias de análisis en la semiótica del espectáculo}

experiencia-cuerpo-emoción

$E_{\text {s la función del espectador que resulta lo más }}$ cercano a un punto de partida irrenunciable. No creía posible continuar con los estudios que se hacen desde distintos puntos de vista, entonces me interesó señalar la experiencia de una realidad artístico-, estética que se presenta en el espacio escénico y que de manera imprecisa invade al espectador que no repara en ella hasta el momento en que se siente afectado, violentado, sin ser objeto aparente de ese proceso.

Percibir, tener la experiencia, concluir que algo ha llegado a interrumpir el ritmo de la respiración y nos impulsa a sentir euforia, emoción, alegria y dolor, es una parte de la creación que está siempre en el espectáculo.

Nadie duda que el sujeto espectador es un cuerpo en un mundo en el que transitan emociones que lo penetran y lo enajenan, lo niegan y lo invaden al mismo tiempo. Hablar de la experiencia es referirse tambièn a la realidad que se vive y se recuerda. 
La experiencia a que me refiero da paso a la memoria, la experiencia de la memoria es otro modo de recuperación de la historia personal.

Philippe Julien estudioso de la obra de Jacques Lacan (p.15) afirma que es el inconsciente el que entrevee lo real a través del "malentendido". Tiene el inconsciente un ingrediente que es la memoria, "finalmente el inconsciente no olvida" porque no hay adentro psíquico sin relación con un afuera cultural y político.

La idea de experiencia privada es indiscutible según la cual tenemos un conocimiento inmediato infalible intrinsecamente subjetivo de contenido a través de las representaciones e ideas que produce un espectáculo.

Esta idea de experiencia algunos la llaman "lenguaje privado" se limita a nombres de sensaciones o de experiencias- dolor-rojo- cuya significación será fijada exclusivamente por experiencias privadas, dice Wittgenstein.

Todo lenguaje supone verdaderos criterios y reglas públicas de uso de expresiones y la consecuencia es previsible ya que toda concepción que define lo mental por su carãcter privado es incoherente.

Las experiencias, agrega Wittgenstein, como otros estados psicológicos definen "nuestros juegos de lenguaje" con ciertos criterios objetivos y públicos.

¿Está necesariamente influido por juicios o inferencias el contenido de nuestra experiencia? Sölo hasta cierto punto.

Algunos filósofos insisten en el hecho que la percepción no es una recepción pasiva de lo dado como las ilusiones visuales o la percepción de figuras 
implican cambios de forma.

Una matriz conceptual se requiere para que un sujeto pueda aprehender el contenido de una experiencia. R. Gregory (1970) entiende que la percepción es comparable a un hipótesis, pero no alcanza a aprehender que el contenido de una experiencia visual, por ejemplo, se identifique con juicios fundados en esa experiencia.

Hay que distinguir el contenido representacional de la experiencia que vehicula una información no conceptualizada. Si no se hace esa distinción no se comprenderia por qué en una ilusión visual la ilusión permanece aún después que se ha tomado conciencia de su naturaleza ilusoria.

¿Por qué lo espacial y no lo temporal es intrínseco a los contenidos perceptivos? El mismo contenido perceptivo puede ser alcanzado en momentos diferentes y por procesos perceptivos distintos, mientras que una traslación espacial modifica los contenidos perceptivos pero no los procesos.

Reciprocamente una traslación no conserva la identidad de la ocurrencia del acontecimiento sensorial aunque conserve a menudo el contenido perceptivo.

Para Christopher Peacocke (1992) esa disimetria entre las propiedades temporales y espaciales en la experiencia proporciona el embrión de una teoria de la realidad, ya que permite disociar las presiones propias al acontecimiento sensorial de las que son propias a su contenido. Es una ocurrencia que diferencia una visión englobante de la percepción: en los ingredientes sensoriales y el contenido que implica. 
Cada fenómeno perceptivo tiene una referencia a la realidad y guarda permanentemente el trazo de acciones efectuadas a fin de extraer la información espacial propia a lo referencial objetivo y aún en el espacio egocéntrico.

Los procesos perceptivos afirma Pascal Engler, el autor del articulo sobre la "Experiencia" al que me refiero publicado en la Encyclopédie Universalis ponen en juego acciones tales como el enfoque del ojo, la orientación de los ojos en las órbitas y la cabeza y un comportamiento más global de orientación.

Como se verá la codificación de la acción es probablemente operada a nivel de las intenciones no de los comportamientos propiamente dichos.

Hay dos aspectos de los procesos perceptivos que suceden al espectador cuya atención está alerta en la tarea que lo compromete el espacio escénico: el aspecto temporal de un proceso que lo inserta o incluye en una serie ordenada y la información espacial puesta por el proceso, condición inicial que el sistema introduce para calcular las constantes de dirección y posición visuales.

La información espacial es típicamente redundante en el caso de una experiencia local, es en ese sentido que ella está presente en cada señal sensorial pues es garantía de equilocalidad que proporciona una condición necesaria del carácter objetivo de la experiencia, considera Joëlle Proust (p.13).

La mayoría de los psicólogos contemporáneos admiten que los sistemas de tratamiento de la información sensorial son autónomos en relación con los procesos superiores de pensamiento y juicio. $Y$ 
como informa el artículo a que hago referencia más arriba, según Fodor (1981) vehiculan una información "modular" que tiene carácter rápido, automático, aislado, en relación con los contenidos de los procesos centrales.

La idea de 1o "modular" de Fodor tiene otros origenes lo que confirma que seria una caracteristica de determinado, cuasi automático.

¿Podria ser eliminado el contenido subjetivo de la experiencia?

Es dudoso, porque siempre lo señalamos como último recurso, quiere decir que nunca está ausente. Este tema está desarrollado en propuestas científicas.

La imagen cientifica del mundo no es la única real y la visión subjetiva que nos da la experiencia es irreductible.

Lo que se llama la experiencia es muy diverso en un mismo sujeto. Tiende a mostrarse como unificadora, como sostén de un sujeto. Pero también se distancia del sujeto para abrirse a otra experiencia al instante siguiente a causa del objeto que provoca esa movilidad de la experiencia.

En el sujeto el conocimiento de la experiencia tiene que ver con el mundo de la cultura, de la significación y resulta el meollo del análisis del espacio escénico.

Hay una dimensión significativa que alimenta y comparte el espacio escénico con la necedad. ¿Por qué la necedad? El discurso analítico dice Lacan nos acerca a lo compacto, a lo tenaz como a lo que llamamos necedad que tiene la caracteristica de un espacio estructurado y que por ello reúne conjuntos que percibimos en el espacio escénico. 
Elijo el discurso analítico porque es afin a la tendencia que reconoce elementos en un espacio. No es lo contrario de sintético porque no se refiera a una totalidad, sino que establece conjuntos que significan. El discurso analitico es el que enuncia el psicoanalista cuando habla y escucha. Tiene caracteristicas que relacionan el habla y la escucha porque están en relación con la significación.

Los elementos del espacio mental, escénico, físico parecen aperturas, espacios abiertos que vamos integrando no son homogeneos, hay intersecciones, es un secreto de la significación.

\section{lengua, significante, inconsciente}

$L$ a referencia al inconsciente es una posibilidad para salir de la teoria de las interpretaciones ya que el significante representa al sujeto y el signo es algo para alguien.

Un ejemplo próximo y no por eso banal es el del fuego que tiene un significado, mientras que el significante permanece abierto a todas las significaciones hasta que otro significante se relacione con él. Esto produce una significación inesperada.

Cuando Lacan dice que "el inconsciente está estructurado como un lenguaje" no dice de qué lenguaje se trata, pues vamos del más estructurado al estructurado y de lo más a lo menos forzado.

$\mathrm{El}$ análisis del trabajo escénico es una práctica en la creación del espectáculo que aplica el psicoanálisis a la función del espectador, el inconsciente del sujeto traduce una significación que 
le ocurre. De signo en signo, como afirmaba Peirce reconocemos la semiosis.

No hay signo fuera de la semiosis, ésta circula con el ritmo de los significantes, ya que a Peirce no le interesan los significados, no habla de lingüistica, que es el asunto de Saussure.

Vimos que poco se ocupó Saussure de la semiótica y es Hjelmslev quien nos aclara la función de la semiótica, no "necesita" de los signos sino de las figuras. ¿Por qué este reemplazo? Porque era la posibilidad de desplazar al signo, según Hjelmslev.

Algunas observaciones de Mustapha Safouan me permiten asociar una expresión que Freud utiliza "condiciones de figurabilidad" -cambia el sentido de una frase cuando se cambia de lugar una coma- con la noción de figura que usa Hjelmslev. (Ejemplo: ¿Cómo estás? ¿Como, estás? Y asi de continuo).

Cuando hablamos del inconsciente estamos inevitablemente enredândonos en problemas de lengua.

¿Qué hay en el inconsciente? Lo que está ausente o no está consciente que es otro texto que no conocemos y está bajo el texto que enunciamos. Dice Lacan.

El saber es un enigma que está presente en el inconsciente como se revela en el discurso analítico

Por lo general se enuncia que el lenguaje sirve para la comunicación. 
La comunicación implica la referencia. Sólo una cosa está clara: el lenguaje no es más que lo que el discurso cientifico elabora para dar cuenta de lo que yo llamo la lengua.

La lengua sirve para otras cosas diferentes de la comunicación nos lo ha mostrado la experiencia del inconsciente, en cuanto está hecho de lalengua, esta la lengua que escribo, en una sola palabra, como saben para designar lo que es el asunto de cada quien.

Lalengua llamada y no en balde materna (Tomo 20: p. 166).

El asunto de cada quien es lo que aparece con el inconsciente, que nos introduce en el tema de la significación.

surge la significación

Cuando el inconsciente se libera de la represión en que vive es en definitiva un resultado de la relación del sujeto con los significantes.

Por ello nos referimos al sueño, al chiste, al lapsus, $y$ al sintoma en el sujeto que constituye formas diferentes por la incidencia del significante. $\mathrm{El}$ sujeto es el mismo sujeto que compone culturas.

Peter Brook utiliza la noción de significación y no soslaya la relación que establece la lingüistica entre significado y significante cuyo producto es el signo, que es un valor clasificatorio pero no del orden fenōmenológico, porque no agota el acto semántico.

El signo vale en un entorno, nunca está aislado. Saussure utiliza en su obra pionera una imagen que sigue siendo válida: la de una hoja de papel que se 
recorta en varias partes y cada una tiene un valor en relación con las otras, pero también cada parte tiene un derecho y un envés que han sido recortados de la lengua.

Roland Barthes dice que estas asimilaciones que se señalan entre las dos caras de una hoja o de un recorte son las articulaciones en el dominio de la lengua y el sentido está antes que todo recorte.

La tarea de la semiologia/semiótica es mucho menos establecer un léxico de objetos que las articulaciones que los hombres hacen sufrir a lo real. Un saussureano agregaria un dato peyorativo, pues asi como las propiedades de los objetos no están incluidas en el significado, no intervienen en las clasificaciones inherentes a la lengua, Aristóteles dixit: el significado hombre no incluye el rasgo plumas.

La significación no une seres unilaterales, no aproxima dos términos, porque significante y significado son cada uno término a relación. El signo que Peirce alude en la semiosis tiene esas caracteristicas, al no existir aislado no hay otra posibilidad que encontrarlo en su articulación con otro signo.

El asunto de la significación que está en el título del libro se extiende hacia la posibilidad de "conocer" la escena cuyo texto se reproduce.

No se trata de interpretar un sueño, Laplanche retoma esta afirmaciōn en una "contrahermenéutica", sino de aprehender su significación cuando llega el momento. Este momento está al final en función del fin que está al comienzo en el sueño o la metáfora, cuyo significante se sustituye y tenemos que esperar para esclarecer la metonimia. 
El significante tiene autonomia lo descubrimos asi aparece la experiencia del espectáculo porque el significante aislado no tiene significación alguna.

Cuando Stendhal usa un vocablo italiano, el significante, no es sólo el término utilizado, sino el hecho de haber utilizado tal vocablo para expresar una cierta idea del autor que ha decidido recurrir al italiano y ese recurso tiene por significado una cierta idea de libertad ligada a Italia.

En fin si el plano de la expresión o significante como lo llama Saussure es ya un lenguaje se trata de una lengua connotativa, porque connotación existe cuando el elemento significante es el hecho mismo de emplear tal o tal otra lengua y esta noción se ha extendido a los casos en que el significante es no solamente lenguaje, sino ilusión de un discurso ya mantenido o el que estará por realizarse. En este caso las lenguas naturales en el uso literario y aún más allá de ese uso proporcionan un ejemplo constante de lenguaje connotativo, a menudo lo que es el significante es menos el vocablo escogido que el hecho de haberlo escogido. El esfuerzo de abstracción que impone Hjelmslev, finalmente, tiene asi por contraparte una considerable expansión en el campo lingüistico que aprovechó toda la semiologia moderna.

Entonces el significante no se limita, no puede limitarse a ser un soporte fonemático, porque cada elemento de ese significante carga con un sentido.

De esa carga se constituye la semiótica.

Lacan dice que se puede colectivizar el significante, quiere decir que hay colección de significantes que parecen mostrarse en una totalidad pero "no hay predicado que lo permita". 
Jakobson dice del significante que no es una palabra la que puede fundamentar el significante. ¿Y entonces?

Aconseja echar mano a una unidad como el proverbio que es asunto de los lingüistas y se abre a la locución que es una significación.

La variedad de proverbios penetran en una variedad de significancias ese seria el lugar del significante que buscamos: lo que produce efecto de significado.

Aclara Benveniste que la relación de arbitrariedad entre los momentos del signo parece no tener nada que ver con lo que lo causa, con el referente y "si no tiene nada que ver con lo que lo causa es porque se espera que tenga cierta relación con lo real" (T20/ 29).

Para Lacan ese referente es una muestra de un "yerro". La relación del significado con lo que alli estã como tercero indispensable, el referente, es propiamente que el significado lo yerra. Porque si el significante lograra la imagen que necesitamos para ser felices "todo estaria muy bien, pero no es el caso".

¿Hay acuerdo con el referente o con un referente? Para Peirce esta pregunta no tiene sentido.

Volvemos a la pregunta ¿cómo caracterizar el significante? Seria una variedad, un colectivo, no es una categoria semántica sino un modo de "colectivizar" de lo que se puede concluir que no es portador de mensaje.

Por qué dice Lacan acentuamos la función del significante, porque es el fundamento de la dimensión de lo simbólico. Valga la relación con la cultura.

Lo simbólico, la cultura, lo que queda en el 
espectador luego del espectáculo es el mundo de significantes que no configuran mensaje como los significados. La relación equivoca con el espectáculo se instala cuando alguien pregunta: "¿a ver qué quiere decir?" No quiere decir nada.

Francoise Dolto, eminente psicoanalista de niños afirma que el niño habla desde donde está, cuando dibuja o pinta se ubica ante el papel de otra manera, no tiene nada que decir o no quiere decir nada. Es la dimensión que los adultos han perdido de vista, han extraviado el lugar, su lugar desde el que hablan y le preguntan al otro: sea papel o libro o amigo.

Considero esclarecedora esta observación de Francoise Dolto como sucede en la teoria psicoanalitica hay que partir del sujeto y esto lo confirman los semióticos.

Resumiendo: saber dónde estoy abre la posibilidad de hablar. Frente a esta situación que es primigenia el adulto huye, se considera "al desnudo" y no regresa a ella. La observa como limitante, es decir "subjetiva". Lo subjetivo está en el espacio estructurado del conocimiento del sujeto.

Este temor o retraimiento ante 10 "subjetivo" es lo que ha generado tantas páginas que son prescindibles en un discurso que cuestionamos.

\section{el discurso}

que se oye acerca del espectáculo o lo que se oye en el espectáculo no tiene relación con lo que significa porque se instituye en un discurso cientifico. Quiero decir que no tiene nada que ver con el significado.

Lo que Saussure llama arbitrario cuando observa 
al signo, es lo que le sucede al espectador.

Lacan cita al Cratilo de Platón que reafirma que el significante no tiene ninguna relación con el significado (T.20/41), y que lo llamado arbitrario en la relaciōn que reconoce Saussure en realidad se trata de otro discurso que se desliza al discurso del otro. Entonces arbitrario no es lo que cuadra. Hay que salir del discurso porque lo arbitrario indica que puede acudir a otra referencia.

Dicho de otra manera, si el significante fuera arbitrario no es lo mismo que decir simplemente que no tiene relación con su efecto de significado sino que es apuntar a otra referencia.

Cuando Lacan dice "referencia" (T20/41) sólo puede situarse a partir de lo que el discurso constituye como un vinculo y agrega:

el significante como tal no se refiere a nada que no sea un discurso, un modo de funcionamiento, una utilización del lenguaje como vinculo. En definitiva el uso.

Vinculo es el vinculo entre los que hablan, los que tienen vida (p.42).

Vida tiene que ver con muerte, resulta entonces una ambigüedad significante, porque para definir la vida no hay más que acudir a la reproducción del cuerpo. Pero esta dirección es, no se define, como la existencia del mundo, la cópula es el lenguaje.

El discurso corriente da una lectura diferente al significante del espectâculo que resulta más próxima de la experiencia del "lapsus" o del chiste.

Es la evidencia que hay algo dicho que "no se ha querido decir". 
Lacan se pregunta y forma parte del recorrido de este trabajo:

¿Cómo pudo omitirse el papel fundamental de la estructura del significante? Evidentemente, comprendemos por qué. Lo que expresa en el seno del aparato y del juego del significante es algo que sale del fondo del sujeto, algo que puede llamarse su deseo.

A partir del momento en que el deseo está capturado por el significante, es un deseo significado. $Y$ todos estamos entonces fascinados por la significación de ese deseo. Y olvidamos, a pesar de que Freud lo recuerda, el aparato del significante..." (T.3/342).

El significante, ese dato que aparece en el sueño es el dato o "sintoma" de una historia que hemos olvidado. Ese sintoma basta para demostrar la importancia esencial del significante.

Algo que "no se ha querido decir" es la evidencia del inconsciente. La aparición del inconsciente "se dice" y nadie se hace responsable de esa nueva frase que nadie explica aunque todos parecen resueltos a explicar.

Un comentario de Lacan ilustra esta experiencia. Se refiere a Joyce el escritor cuyo lenguaje pareció siempre intraducible:

El significante viene a rellenar como picadillo el significado. Los significantes encajan unos en otros, se combinan, se aglomeran, se entrechocan y se produce algo que como significado puede aparecer enigmático, pero es lo más cercano a lo que nosotros los analistas 
gracias al discurso analítico tenemos que leer: el lapsus (p.49).

El lapsus puede leerse de diversas maneras y se parece a lo que sucede al espectador que recibe el texto que oye y que ve. Porque leer y oir está lejos del discurso que está escrito.

Cada uno tiene su particular lectura. La abeja, dice Lacan hace su lectura del entorno cuando tiene que cambiar de ruta o cambiar de decisión.

Leer algo distinto a lo que está escrito es una fatalidad que le conferimos al inconsciente, a su "capacidad" de leer y por qué no a su capacidad de "aprender" a leer.

Leer algo distinto a lo que está escrito no es "equivocarse" porque enseñar a leer:

no tiene nada absolutamente nada que ver $y$ en ningún caso con lo que ustedes pueden escribir. Ipso facto son espacios diferentes (p.49).

Algunas observaciones de Jean Laplanche aclaran este delicado tema:

¿Hay en el inconsciente algún significado, un mensaje a comunicar y a liberar? Pues bien hay que tener en cuenta lo siguiente que cuestiona nuestra tentativa de definición del lenguaje: el inconsciente es un fenómeno de sentido, pero sin finalidad de comunicación.

Y agrega que el inconsciente habla si se puede decir así, pero no vehicula un mensaje. En el sueño, en los sintomas del lenguaje como el lapsus, por ejem- 
plo hay que insistir que son las formaciones del inconsciente cerradas sobre ellas mismas y no están destinadas a la comunicación.

La razón que esgrime Laplanche es que la comunicación no existe sin un mínimo de estructura, no se puede hacer pasar un mensaje sin código (p.123).

La aspiración es aplicar un análisis semiótico a un espectáculo teatral cuyo espacio escénico es abstraido por el espectador en su tarea de espectador. Quiero decir que está abierto y cerrado. Abierto porque se propone ensanchar la percepción del espectáculo no sólo para él sino para el conocimiento de los estudios sociales y humanísticos. Y cerrado porque en sus espacios mentales resuena la novedad que lo afecta.

La insistencia de la complementariedad de las diversas miradas o enfoques en el ejercicio semiótico es irreversible, como en cualquier exploración cientifica. En la lengua, utilizamos expresiones que completan y complementan y de esa manera aclaran la idea primera sobre un objeto, la enriquecen o la rechazan.

El objetivo o punto de vista o propósito del presente trabajo es introducir los elementos que surgen de una experiencia novedosa y personal que puede interesar a otros sujetos espectadores. Porque cada uno vive "internamente" un modo de conocer y conocerse que estimula la experiencia de la escena, siempre que desista de la "maravilla" que representan las ideas fijas del espectador o del critico que buscan "sin piedad" un mensaje, una idea, una función llegada desde fuera de sí mismo. 


\section{intersubjetividad}

En estas variaciones de complementariedad la intersubjetividad es inevitable e insoslayable pues es generalmente reconocida en los estudios sobre la lengua por la relación dialogal que enuncia el "yo" al instalar sin duda al "tú".

Es además recurrente en los estudios sobre la estética, pero el interés de esta perspectiva reside en el espectador y por ello recurro a la noción de transferencia. Expresión propia de la relación entre paciente y psicoanalista. La extensión del significado conviene para la semiótica del espectáculo que propongo.

\section{transferencia}

La transferencia tiene que ver particularmente con la emoción que nos brinda una imágen o "la encarnación de lo simbólico vivido en lo imaginario". Simbólico, como esta dicho con anterioridad está ligado a lo cultural y atrae infinidad de imágenes que modelan lo vivido por el adulto que adquiere el compromiso imaginario de la aceptación originaria, primera o primigenia.

Cuando se dice emoción se refiere a un hilo conductor que recorre el espectáculo que es objeto de nuestra experiencia. Pero también se abre a la significación, ya que una significación de esa emoción remite a otra significación que es su destino o su "salida".

Si se buscan "otras salidas" como la explicación que proporciona el "entorno social" o las razones literarias del texto dramatúrgico o la confluencia de 
intereses que representa un autor notable o la recurrencia a la siempre vigente fuerza de la puesta en escena como elementos coadyuvantes de un espectáculo quedamos instalados en la antigua semiótica.

La transferencia se produce ante el valor de la palabra, no por su ambigüedad sino porque la palabra es función de lo simbólico, del pacto que une al sujeto en una acción.

La acción humana está fundada originariamente en la existencia del mundo del simbolo a saber en leyes y contratos (Lacan I/335).

El discurso del espectador se funda en la transferencia que ocurre en el plano simbólico durante el espectáculo, por esa relación que no es solamente adquirir un boleto, sentarse en la sala, disponerse a "estar", sino que el plano simbólico es el único lugar del discurso aparente que es el discurso del inconsciente, que aparece enmascarado. Suele suceder que todos los discursos parecen enmascarados o aparentes por su calidad retórica.

Las viejas figuras de la retórica o arte del orador fueron ejercicios que cautivaron durante mucho tiempo a la humanidad y según Lacan esas figuras retóricas están en el fondo de los mecanismos freudianos.

Freud -dice Lacan- encontró en su práctica médica que los mecanismos del lenguaje dominaban $y$ organizaban sin que lo supiera el sujeto fuera de su yo consciente, la construcción de ciertos trastornos que se llaman neuróticos. 
En el sueño escuchamos a quien nos habla (I. p. 358)

y asi aparece el Otro que establece un diálogo y se instala la intersubjetividad que es la prueba de la variedad de los sentidos. Diálogo que se realiza entre sujetos que participan del espectáculo pero también entre cada espectador y el mismo espectáculo.

\section{intersección}

Las dos sustancias que reconoce Hjelmslev en el significante y el significado conducen a otras preguntas, visto desde el psicoanálisis no en la lingüistica.

El significante se remonta a los estoicos, a San Agustin y debe estructurarse en términos topológicos, en el desarrollo que hace Lacán (p.27).

El significante es primero porque produce efectos de significado y es importante no eludir que entre ambos hay una barrera que franquear, es justamente la intersección.

Juri Lotman también apunta a la intersección que hay que franquear como frontera entre lo conocido $y$ el resto, la cultura ajena. Algo que puede entenderse como la separación entre la sala y la escena en un espacio en términos topológicos, porque significan. - Lacan no cita a Hjelmslev pero dice que la manera de topologizar, de hacer lugar en lo tocante al lenguaje está ilustrado de manera admirable por la fonologia en cuanto encarna el dilema del fonema que tiene 
rasgos determinantes, permanentes y variables.

La fonologia es el signo del lenguaje contrasta con la fonética que es sonido del habla asi lo distinguieron los miembros de la Escuela de Praga. Pero el significante no se limita, no puede limitarse al soporte fonemático, cada elemento de tal significante carga con sentido y no es aislable. Lacan introduce la propuesta de Saussure que situia al significante, la pura corriente del discurso, la sucesión de palabras donde nada es aislable (T3/373).

Peter Brook refrenda esta propuesta. Es uno de los teóricos y dramaturgos de origen alemán, cuya obra es la huella más definitiva hasta la fecha, para pensar y estudiar las artes escénicas.

Autor de El espacio vacio y varios trabajos que responden a los intereses y señalamientos propios al director-dramaturgo afirma a propósito de la relación entre significado y significante (p. 102).

Que el teatro es siempre una búsqueda de "significado" como un modo de hacer que ese significado diga algo a los demás. Admitir ese misterio es no perder la capacidad de asombro, ya que sin él la vida pierde su significado. Siempre habrá una escalera que conduce de un nivel a otro. Los peldaños son detalles, los más minúsculos, momento a momento. Los detalles son el arte que conduce al corazón del misterio (p.102).

Confiesa Peter Brook,

cada vez que hablo en público realizo un experimento, intento atraer la atención hacia 
el hecho de que nos hallamos en ese momento en una situación teatral. Visto asi observamos con detalle el proceso en el que estamos, podremos considerar el significado del teatro de un modo menos teórico (p.103).

La esencia del teatro se halla en un misterio llamado "el momento presente".

¿qué es un momento?

Si pudiéramos penetrar en el corazón mismo de un momento, descubririamos que no hay movimiento, que cada momento es el conjunto de todos los momentos posibles y que lo que llamamos tiempo ha desaparecido (p.107).

Lo dicho no acaece en nuestra relación con el mundo exterior. Asi pues en un espectáculo teatral nos hallamos ante la presencia de una ley inevitable cuya tendencia es hacia el momento de mayor significación. Necesitamos una cadena de momentos que empiezan en un nivel muy simple, que nos conduzcan hacia la intensidad y luego nos aleje de nuevo, Son las reflexiones del estudioso que afirma (p.108).

Pues si en ese momento se liberara el poder oculto colectivo de pensamientos, imágenes, sentimientos, mitos, traumas serian tan poderosos y podia resultar peligroso. Pareceria una explosión nuclear y el caótico torbellino de impresiones seria demasiado intenso para que alguno de nosotros pudiera absorberlo. 
¿Cómo captar un momento en que actor, director, autor y escenógrafo se unen en un gran esfuerzo común? pues ninguno de ellos puede hacerlo solo lo que contribuye a la unión entre un nivel cotidiano y uno oculto del mito. En ese espacio escénico hay una experiencia compartida o pretendidamente compartida pues el actor provoca una reacción en cada espectador que es un aspecto de la realidad que evoca el actor. Se puede suponer que es el material básico: la historia, el tema que está ahí por encima de todo y proporciona un terreno común.

El teatro no es una discusión entre personas cultas, afirma Peter Brook, la mayor de las ambiciones es "atrapar un pez dorado" que vendrá de algún inconsciente. Gracias a la energia del sonido, el color y el movimiento pulsa una tecla emocional que a su vez estremece el intelecto (p.109).

El secreto para atrapar "ese pez" está en la red.

La red debe ser como construir un puente entre lo que somos habitualmente bajo condiciones normales llevando nuestro mundo de cada dia con nosotros y un mundo invisible que sólo se nos revela cuando la habitual incapacidad perceptiva es sustituida por una conciencia infinitamente más aguda.

Peter Brook no habla de la verdad porque escapa a toda definición y comprensión en estas regiones del sentimiento, ya que el teatro es una máquina que permite a todos sus participantes saborear por un momento un aspecto de la verdad. El teatro es una máquina para trepary descender por las escalas de la significación (p.111). 
El espectador se acoge al miedo que es sinónimo de emoción ante lo desconocido. Puede ocurrir la repetición de algo conocido cuando se aventura al juego de la imaginación ya que la verdadera forma, dice Peter Brook, llega a último momento. Es como un nacimiento, luego de que las versiones de cada espectador parecen padecimientos de los que el espectador tiene que tomar conciencia.

Una gran emoción que atraviesa al espectador transforma la cualidad en calidad del silencio.

Un momento después se puede estar en silencio, un silencio completamente diferente y asi de continuo.

Por esta razón la idea de construcción-demolición se presenta en cada creador y está ligada al miedo que se siente cuando no hay muletas ni apoyos externos cuando termina el acto mecánico o convencional de la creación, se acaban las formas rígidas, esperadas, conocidas.

Peter Brook inmortalizó la expresión "El espacio vacio" que es el titulo de uno de sus libros, para ubicar ese lugar sin decorados que no tiene historia y se encuentra en el sujeto. El sujeto crea un espacio interior, un vacio interior, en el que nace una nueva tension, una nueva significación.

Humberto Eco expone que la emergencia de la significación se podria evocar en términos dualistas en la problemática general humana, cuando pregunta

¿Cómo se pasa de una realidad que no es física a un continuo material?

¿Cómo vehicula el sentido la construcción especifica de una actividad mental que existe mâs 
allá de la epidermis a través de los elementos de tipo material heterogéneo, externo, componiendo diversos lenguajes y poseyendo una dinámica estructural propia? (1978/182).

Invertimos la pregunta: ¿cómo pasar de un continuum material a una realidad no fisica? ¿Quiere decir lo mismo? Es un acuerdo, una convención, diria la lingüistica verbal, establecida o prestablecida entre los seres humanos.

La semántica que reside en la lexis o lexicalista no se plantea más que como el fin de una semántica y ocupa las etapas que se refieren a la convención. No explica cómo se ha elaborado el sentido, cuáles son las estructuras propias, lo que pasa en el nivel de la expresión antes de que el consenso se establezca.

El nivel de la expresión recorre el espacio escénico cuando la experiencia conocida se concreta en el teatro con lo desconocido de nuestra subjetividad. Objeto cercano y a la vez distinto.

la música en el espectáculo

Ni modalidad, ni tonalidad, ni cromatismo, ni ruido, parece que necesitamos una guia para explorar el laberinto de las músicas. No solamente los ruidos se transforman en música, sino la música se transforma en ruidos', es decir en otra música.

Porque lo que se escucha es una sonoridad que abarca toda problemática de pulsiones y de impulsos rápidos y lentos como "si fuera una topologia rítmica y refinada". 
La proximidad del análisis musical con la propuesta de Hjelmslev se refuerza cuando Anne Claire Désesquelles dice que la forma es una fuente de sentimientos y participa plenamente de la expresión, el oyente tomado por la obra no puede eludir el camino patético (p. 749).

La forma produce tensiones y distenciones a gran escala que integran los elanes y recaidas más rápidos de la melodia. De modo que ambos concurren a la expresión de un mismo sentido. La energia no podría existir sin la forma. Una forma desprovista cuyas partes son externas unas a otras indiferentes al desarrollo musical que las ocupa.

En el artículo que comentamos más arriba hay un señalamiento que la música es el

arte más cercano de la arquitectura por sus simetrias, sus regularidades, sus composiciones, pero también la más alejada en razón de la fluidez y de la manera tenue de sus vibraciones sonoras que se oponen a la permanencia de las masas arquitectónicas (p. 728).

Dice Joëlle Proust que las cualidades de la sensación tienen una información espacial lo que puede llevar a separar el velo de la percepción y transgredir las presiones de la objeción fenomenista.

¿Pero dónde reside la objetividad? $\mathrm{El}$ investigador $y$ es opinión generalizada opina que reside la objetividad del lado de la experiencia del sujeto, en la capacidad de discriminar un contenido perceptivo complejo, coherente. El estudioso de la percepción explica que es una teoria causal la que puede dar razones categóricas del lado del objeto. 
El fenómeno, lo musical, da una información espacial redundante que fija las condiciones de la unidad y de la repetibilidad de la experiencia.

Al espectador le sucede que puede llegar a sentir con el fenómeno musical lo que pasa en el espectáculo y lo deja pasar. Otras veces lo amarra todo en el presente del espectáculo y ese presente se siente en la sala de diferentes maneras.

\section{¿por qué no la topología?}

Hablar de un lugar en el espacio escénico es citar la topologia.

El espacio escénico, el lugar desde el que hablamos instala la topologia que ocupa otras dimensiones en las ciencias humanas y sociales. Hay una dimensión imaginativa que el sujeto reconoce en el espacio escénico, espacio estructurado, compacto y tenaz porque está presente con fragmentaciones o sin ellas.

La idea de espacio estructurado es afin a la idea de conjuntos en un espacio homogéneo, son conjuntos abiertos que se cierran para la ocasión. Estos conjuntos abiertos que están tambiên próximos a los márgenes de la cultura muestran que el espacio no es homogéneo. Quiere decir que hay intersecciones que separan. Lotman cuando se refiere a la semiosfera, alude al espacio y las intersecciones y las fronteras.

La topologia da lugar al espacio geométrico que define de manera diferente al espacio conocido como sala y escena y esa diferencia reside en el cambio 
que soporta el espacio. Las nuevas formas de una topologia repercuten en la escenificación que no es un hecho gratuito de un director.

Alli estân también los objetos que actúan antes de tener un nombre propio en la escenificación, porque tienen tambièn su propia historia.

\section{estamos en un mundo de objetos}

La topologia y los objetos hablan y el espectador escucha, comparte o rechaza porque la experiencia del sujeto se ensancha por su participación en el espectáculo.

En palabras de Veronese: el texto es desbordado por la plástica, el objeto por lo coreográfico que hay en él, el gesto por la palabra inadecuada, inesperada para el propio gesto.

Lo que sucede es el cambio de la forma única, ambivalente, plurivalente que incentiva y fomenta el encuentro con signos dramatúrgicos no reconocibles en las zonas de oscuridad y de misterio, porque:

hay un encadenamiento entre teatro de objetos y teatro de actores.

Mutuamente se van descubriendo. Se van descubriendo sin ser lo que esperamos. El teatro se resuelve en una poética de tres elementos: la sintesis, la repetición obsesiva del elementos sintetizado y la obscenidad, agrega Veronese en los Mandamientos que figuran en La deriva.

Teatro es un infinito depósito de objetos 
transformables y según algunos autores la identidad y significación del objeto se distingue del mundo fenomenal o sensorial del que extraemos los indices para inferir una idențidad. Esto se traduce en la distinción entre fenómenos perceptivos.

Los psicólogos Gibson como anteriormente Titchener (1916) citados por J. S. Bruner insisten en la distinción entre el campo visual y el mudo visual. El primero estudia el dominio de las impresiones sensoriales atributivas y el segundo el de los objetos, las cosas, los acontecimientos.

Pratt, también citado por Bruner, insiste en el hecho que la motivación, la actitud y la experiencia anterior, pueden afectar los elementos del mundo visual, el de lo objetos pero no los datos del campo visual (p.4). Los objetos están actuando antes de tener un nombre, son formas.

En un estudio sobre Semántica del objeto Roland Barthes anota que si bien hasta ahora la lingüistica ha estudiado cómo los hombres dan sentido a los sonidos articulados, hay que investigar cómo dan sentido a las cosas que no son los sonidos (p.249). Lo que se ha hecho hasta ahora es rudimentario, como el código de rutas, y el resto, todo lo que significa está siempre mezclado con el lenguaje

no hay jamás sistemas significantes de objetos en estado puro.

Y el objeto, como el signo estã en el cruce de dos coordenadas o dos definiciones: la simbólica y la de las clases o significación. 
Por qué ningún objeto escapa al sentido ¿cuándo se produce la semantización?: desde que el objeto es producido y consumido por una sociedad de hombres, desde que es fabricado.

Brecht señala en un texto sobre un cierto número de puestas en escena que hay un largo y complicado desarrollo que hacer sufrir a los objetos para hacerlos significar tal concepto. Pues la ley del teatro dice que

no basta que el objeto representado sea real, es necesario que el sentido se dé de alguna manera separada de la realidad, no basta presentar al público un vestido de cantinera realmente usado por alguien que significa usura, sino que hace falta inventar nosotros, directores de escena los signos de la usura (R.B. p. 254).

Finalmente todos los grados de cultura, de saber son situaciones posibles delante de un objeto o de una colección de objetos, porque cada objeto puede evocar nuestra lectura en el nivel que sea que podamos relacionar.

Hay objetos fuera de sentido, como sentidos que transitan de cierta manera, porque su caracteristica fundamental la transitividad es tarea del imaginario humano.

Para Barthes este hecho de cultura es sin cesar naturalizado, reconvertido en naturaleza por la palabra que nos hace creer en una situación puramente transitiva del objeto.

Estamos en un mundo de objetos, nosotros estamos alli como uno de ellos, mundo de funciones, de domesticación total, que puede resultar una 
reconversión de la cultura en pseudo naturaleza y define la ideologia de nuestra sociedad ( $p$. $280)$.

\section{ciencias $y$ artes del espacio $y$ el color}

La semiótica del espacio escénico radica en el descubrimiento de una manera de ver el espacio y a medida que se acumulan o suceden visiones, percepciones y nuevas experiencias la idea original de ese espacio del espectáculo se ensancha para dar lugar a otras maneras de participar.

Ha quedad̆o atrás la participación en el teatro como un ingreso del espectador a la escena, ahora se trata de la complicidad que se establece entre mi vida y el espectáculo. Siempre que la diferencia en la participación en ese espacio entraña una significación. La cultura del mundo moderno tiene especificidades que se manifiestan en los recortes y marcaciones del espacio, en la arquitectura como en la pintura de los paisajes, en las obras de arte o de diseño en el plan urbano y en los monumentos.

Las figuras, interiorizadas en la percepción de la aglomeración urbana determinan funcionalmente los usos del habitat. La aglomeración como proceso de agregación, figura de composición y de integración de su historia lenta, la aglomeración como territorio, figura de la empresa urbana de la escala y de la orientación de una geografia social son materiales de arquitectura, pero tambiên aparecen en el espectáculo.

Las formas de significación entran en relación con la expresión arquitectural, formas descomponibles en elementos cuya combinación es susceptible de 
conmutación y de sentido.

El juego de formas contenidas y de sus figuras muestra la importancia del contexto, según el cual un espacio proyectado es un conjunto que tiene unidad de principio y medida.

La idea de una forma arquitectónica llega al teatro con la certidumbre que entre una frase y otra no hay una relación como en la vida, se trata de una relación arquitectónica entre una tensión y otra. Por esta via Felipe Leal, arquitecto mexicano, señala lo que sucede en los edifícios de una ciudad. La visión de un teatro estructurado tiene que ver con la energia que lo alimenta y la tensión que lo sostiene: una manera de conocer el espacio escénico asimilando las experiencias de la ciudad.

Para estudiar las ciencias del espacio se requiere tener en cuenta el espacio natural y el espacio vivido y las representaciones del espacio, como el encanto de los pequeños lugares. Pienso en las fachadas, las calles peatonales, que determinan modos de aprehensión y estructuración del espacio.

Una invención recorre el espacio en cada proyecto en el que interviene el sujeto como formador de sentido, alli estān los espacios llamados románticos para afirmar al sujeto que interviene.

El espectâculo presenta estas características y también proyecta la deformación del espacio vivido en el espacio representado porque se repiten los conflictos que conocen los cartógrafos entre los textos y las cartas de representación. Se lo llama conflicto ideológico.

Las referencias que concurren a los espacios vienen de las imágenes de las cosas que intervienen y de las cosas que no estando presentes se imaginan, 
como un estudio sociosemiótico de las experiencias de consumo. Se pueden relacionar, pero no son reiteraciones sino como cuerpos móviles que se desplazan a medida que surge el interés por uno $u$ otro de los campos.

En el espectáculo el espacio actual o real, o presente, el espacio virtual, la semiosis y la relación con el mundo requieren o explican una transformación incesante. Tan posible es hablar de uno como de otro, de inmediato hay que referirse al que viene, al siguiente, este fenómeno es irreversible por ello parece que pudiéramos evitarlo o negarlo : hacerlo desaparecer.

Habria un desplazamiento del concepto de lugar que está en el lenguaje escolar a través del discurso de los niños, como en el espectáculo en que los actores se posesionan del lugar y queda asentado como una energia que afecta a los espectadores. Pero también a los objetos.

Las ciencias del espacio pueden acumular tantas experiencias de los usos del espacio como usos puede haber en las construcciones de la ciudad, de la casa, del espacio interior. Todas imágenes que en el espectáculo son factibles y pueden integrarse a la semiosis o caracterización de sentido cultural.

Los estudios de retórica y otros estudios que se refieren a las artes reconocen que el espacio tiene una caracteristica que resulta aparente, tal es la inmovilidad. Lo que no ha impedido jamás a los plásticos multiplicar las técnicas para sugerir el movimiento.

La escultura gana en uno $u$ otro caso sobre la pintura y la arquitectura y es la que no ha suscitado 
estudios sobre semiosis que en cambio si están en la arquitectura.

El arte de construir constituye un sistema de signos y con ellos hay cantidad de mensajes visuales que modifican la realidad y que cumplen funciones colectivas. Como en la lengua estos mensajes de 10 construido se articulan y están ligados al todo que los organiza. El asunto de la articulación del signo sea en cualquier arte del espacio desemboca en la relación con el contexto, con su entorno.

El modelo más cercano es la arquitectura y en ella el urbanismo donde las articulaciones se multiplican desde dentro de la construcción a las relaciones entre los edificios y con el espacio o paisaje.

Así se puede abordar el dominio de la comunicación que como en las artes de la música, de la pintura, la arquitectura y las demás ciencias del espacio se establecen sistemas de comunicación que es de lo que estamos hablando cuando nos referimos a articulaciones que delatan relaciones.

Las relaciones que las ciencias del espacio descubren en el espectáculo todas tienen que ver con los lenguajes de la acción, con el lenguaje de los gestos que produce el arte.

Estos lenguajes pueden ser estudiados en áreas definidas por la acción, cualesquiera sean, y los gestos desde la perspectiva que el estudioso escoga.

Lo que hace falta es justamente unificar los. dominios en los que el espectáculo contribuye a esclarecer un modo de relacionarse.

Otras referencias que son posibles y descubren modalidades" del 'espacio escénico conciernen a la isotopia que puede ser violada en todos los niveles 
de las articulaciones desde los elementos más simples como los objetos aislados colocados para el uso frecuente de la acción escénica hasta los niveles de transmisión de sentimientos y emociones.

El Grupo $\mathrm{Mu}$ al que me refiero ilustra con las indicaciones expuestas la semiôtica de la arquitectura en el Tratado del signo visual. Discuten a Humberto Eco porque opone la arquitectura a otras formas de expresión cuya finalidad es la contemplación de las obras de arte o de los espectáculos (p.407). Eco y el Grupo $\mathrm{Mu}$ admiten que los objetos arquitectónicos y el entorno construido, comunican no sólo sus funciones constructivas de abrigo como significados de sentimientos o de atmósferas exactamente como la música y la pintura abstracta.

Es fácil y natural proyectar diversas significaciones sobre una habitación y se puede hacer lo que propone Bachelard connotar diversos objetos los lugares de la infancia, las cuevas del Vaticano, los balcones. Desde este punto de vista el signo arquitectónico puede ser asimilado al signo plástico y plantea los mismos problemas que él.

Igualmente se pueden relacionar muchas familias de signos motivados estudiados por la semiótica como el indice de su función, pero tambièn índice de su confección, de su enunciación; etcétera.

En tanto que signos plásticos los elementos arquitectónicos tienen formas, colores, texturas. Todo lo que se conoce del funcionamiento y de la organización de este signo puede ser retomado aqui. Sugieren los autores del Grupo Mu una clasificación entre formemas, cromemas y texturemas. Pero dos notas son propias de la arquitectura, teniendo ambas 
su carácter funcional. La primera es su modo de articulación. Sin que la demarcación entre las diferentes unidades aisladas sea siempre estricta, el balcón, el kiosko, no delimitan en espacio, lo indican.

Este señalamiento es particularmente sugerente para el espacio escénico. Hay un modo de integración que juega relaciones de subordinación, de superordenamiento, de coordinación.

La segunda a notar está ligada a la organización. Las diversas modalidades de realización de la función acarrean la existencia de otros tantos tipos sea una casa particular, una estación, un complejo deportivo etcëtera.

El asunto de la articulación del signo estructural alerta la relación entre la arquitectura y lo que la engloba, que es su entorno. Los autores enfatizan que estar en la arquitectura es estar en el espacio interno no es estar en una estatua.

Ese espacio interno sugiere la presencia del escénico. Cuando los arquitectos hablan de altura, parece improcedente para el teatro. Pero el concepto de gótico, como espacio significativo, puede desencadenar una nueva perspectiva en el espacio escénico.

Las dimensiones no se actualizan sino en cada espectáculo por lo cual no es licito afirmar esta dimensión en cualquier circunstancia. Pero me interesa descubrir cómo las exigencias de la función arquitectónica traen otros significados al espacio escénico.

Los autores del Grupo $\mathrm{Mu}$ recorren el tema de la semiótica de la arquitectura para incursionar en la retórica en el mismo dominio. Tanto la disciplina de 
estudios de la arquitectura, como la música deben establecer antes sus objetos respectivos, como sistemas de comunicación para poder validar las variaciones isotópicas o transformaciones secundarias que constituyen las figuras de la retórica.

Espacio y objetos, imágenes y representaciones se entrecruzan en la experiencia del espectador e iluminan una semiótica que es inclusiva.

Es decir que cuántos más mundos se descubran en el espectáculo más integración existe con la creación del sujeto espectador.

Estas dimensiones que me interesa destacar en la semiótica de la significación del espacio escénico, alejan las especulaciones "localistas".

Los aspectos que señalamos: espacio escénico, música, significación, transferencia, subjetividad, no están escindidos, se concatenan y se alertan, se autorizan y se disuelven. Producen la catástrofe de un espectáculo y ponen en duda los principios del arte, consideràdos desde siempre los divos de la creación.

\section{realizar miradas transversales}

Lo que seria como perder el sentido de una totalidad.

Realizar miradas transversales de lo ya conocido. Es como aprender a mirar sin la norma de "mirame a los ojos".

Esta es la particularidad de teatro actual de Veronese que él llama el Teatro Óptico y le reconoce que hay que descentralizar la mirada. Es una curiosidad pensar que nosotros no movemos los ojos 
para ver lo diferente de cada imagen fija. Seria como perder el sentido de la frontalidad.

Siempre se dijo que el cuerpo tenia la movilidad que nosotros le impusiéramos y cuando no es asi, la voluntad ha sido también adoctrinada. Con ello queremos dar por tierra las teorias de la voluntad como modificadoras de nuestra visión del significado.

Sin embargo puedo hablar de mi modo de ver y mirar que recibe un ángulo en perspectiva de ese espectáculo y recorta distintos momentos de un paisaje. Pero esa mirada que va a la escena regresa al interior del yo a tocar lo que reconoce. Ese ir y volver de la acción de la escena a mi yo que no sabe nada de lo que ocurre cuando llega la imagen impregna mi modo de ver. Puedo "recibir" una imagen o "negarme" a recibirla.

¿Hasta cuándo? Hasta el momento en que un acorde resuena en mi historia, en mi manera de ser, ser vivido y logra afectar.

Puedo hablar de la ruptura de esa relación que creo, para que se pueda conocer el regreso a una situación inicial. Siempre se recibe lo que puede afectar. Pero no es lo conocido lo que tiene el privilegio de afectar, es lo que se desvia, lo que salta por encima de lo esperado y logra instalarse en un momento de estruendo.

Puedo hablar de ese espacio escénico, de ese mismo espacio no transfigurado sino recubierto de otra máscara. En una u otra presencia, el espacio puede desaparecer porque la afectación se repliega al espacio interior, a la mente, al cuerpo. A la lengua del inconsciente que no es premeditada, sino que se hace con todo lo que el espectador representa. 
Por este espacio transcurre el espectáculo, un tiempo de la vida de la escena, de los actores y de los espectadores.

$¿$ Cuáles son las unidades que se pueden rescatar, destacar? Estas se refieren a cada invocación, a esa llamada interna del yo que crea en la escena y la sala. Cada sujeto o cuadro es la unidad de acción que abarca el espacio integro.

¿De qué otra manera podemos hablar, si sólo soy un sujeto en ese espacio?

Las reflexiones que se expusieron tienen por finalidad formular la siguiente pregunta:

¿Por qué privar al análisis del espectáculo de esta variedad de evidencias?

Una escena o cuadro es lo que atraparemos para el análisis de la obra de Brecht. 


\section{Santa Juana de los Mataderos}

Santa Juana de los Mataderos que dirigió Luis de Tavira connotado creador fue un espectáculo que presentó el Instituto Nacional de Bellas Artes. La dramaturgia corresponde a la obra de Bertold Brecht actualizada por el equipo de "La casa del Teatro" y contó con la colaboración de varios artistas: músicos, coreógrafos, escenógrafos, director de orquesta, vestuaristas, maquillistas, y el equipo técnico del Teatro "Julio Castillo".

$\mathrm{El}$ programa de mano anota que es

una pieza no aristotêlica que demanda una aproximación especifica de parte del espectador que debe estar en posición de adoptar una actitud definida para el aprendizaje, interesándose en los eventos sobre el escenario y captándolos en sus múltiples interrelaciones y su progresión. Esto señala la intención de una revisión radical de su propia conducta.

No le está permitido identificarse espontáneamente con personajes sólo con el fin de compartir sus experiencias. De modo que no se aparte de su intuitiva apropiacion, sino usando sus acciones y enunciados para poner en orden el proceso total. (No siempre el espectador es llevado sugestivamente a esta 
aproximación por la obra de arte misma, puede obtenerla por algún otro camino, por experiencia propia o por el estudio o alguna otra forma). Editada por John Willet y Ralph Manheim ed. Methuen.

Estas observaciones son una lección de estêtica brechtiana, para que el espectador asuma el lugar que le corresponde, revisar su propia conducta, era la tónica de la época. Diriamos ahora, revisar su historia. Porque hace un viaje de ida y vuelta a nuestra memoria. Es como el viaje de lo vacio a lo lleno que se perfila en lo "visible"del espectáculo, pero a partir de la intuición que le hace ver lo que no puede conocerse de otra manera y ordenar según la propuesta personal las razones de la obviedad que están ocultas.

En definitiva el espectáculo se atreve a mostrar lo que nos atrevemos a "ver".

Decir "ver" ya encierra una imagen interna que nos pertenece. Podemos traducirla, cada uno de nosotros puede llegar a traducir esa imagen, pero solamente si está notificado de que existe "algo" que no es lo que se ve, sino que "se ve". Dos niveles que están acompañados por la memoria de lo que supimos y olvidamos.

$\mathrm{E}$ ingresamos con la libertad de recorrer tierras antiguas o lejanas, los tabúes, los mutis, el mundo escolar, a nosotros mismos, a nuestro inconsciente.

Santa Juana de los Mataderos, fue la escenificación de una historia que habla de Pierpont Mauler, rey de los empacadores de carne que firma un contrato para comprar a sus competidores toda la 
producción, acaparar el mercado y orillarlos a la quiebra. Esta acción provoca el cierre de las fábricas donde laboran cientos de obreros y un agudo problema de desempleo. El empresario asegura su negocio pero los empleados le incriminan la situación de hambre.

Es una carrera por la supervivencia y no tiene limites. Un "Ejército de salvación" completa la imagen explotando las buenas conciencias y la ignorancia de las razones que llevan a esa situación limite.

La puesta o montaje comienza en la gran boca del escenario dividido en dos plantas paralelas al piso. En la parte superior el dispositivo de un matadero al que va entrando un cerdo que mueve su cabeza de derecha a izquierda como no aprobando su futuro destino. En la parte inferior están los espacios para la escenificación de la anécdota, alli entran y salen personajes que gritan, protestan, gimen. Nadie oye. Voces, objetos, música, transgresión. Lo que sucede avasalla, trastoca, revierte, disgusta y a pesar de todo, el mundo no se hunde, el teatro sigue en pie. Sucede un contraste entre escena y sala que podria resumirse en que todos gritáramos al unisono, para que alguien oiga.

Esta baraúnda infernal podria ser también la escena final, si en algún rincón Bertold Brecht riera como confirmando que ha logrado interceptar la normal corriente de la vida de esa sociedad.

Tambien nosotros los espectadores podriamos reir porque el espectáculo está abierto a una nueva resolución o disolución que se revive en el sujeto.

Hay una invocación marcada por la turba de gentes que se atropella y no entiende lo que vive. No es 
un mensaje es lo que se ve o se deja de ver en algún momento privilegiado

Desde el comienzo los dados está echados. El espectador es el que guarda la memoria y se somete además a la tormenta que evoca el espectáculo, porque la memoria es una'forma y hay diferentes formas de memoria en ese tiempo corto o largo

$\mathrm{El}$ acontecimiento de una pieza es la puesta en forma que no se inventa felizmente, no es un logro del director de escena o del músico, es un malentendido asi como lo entiende Peter Brook. Está abierto a una nueva resolución o disolución.

Rendir cuentas de lo que pasa en escena tiene por objetivo desmitificar, romper la magia para volver a crear estados de credibilidad.

El sujeto espectador practica variaciones con la referencialidad de los objetos a los que cede deseos, temores y renuncias: los propios. Hay tambièn quienes aceptan esta escenificación como la farsa de la historia del Capital de Marx.

\section{Teatro de lo inevitable}

Esta obra que trata de lo "obvio" en los mataderos, desarticula lo que está articulado en los hechos. Lo que sabemos y lo que no sabemos, porque parece una fotografia conocida. Lo que debe ser desplazado fuera de la escena, que no es representado a la vista del espectador, porque sigue siendo lo intimo, lo guardado, lo propio.

Lo que no está en la cultura sino en el teatro porque es una revolución. La rebelión no está en el lugar conocido, desafia, lo desafia. 
Dice Veronese que el acontecimiento está en el lenguaje que denuncia todo efecto de realidad (p.24).

"No son signos para interpretar, sino superficies para describir", afirma Bastien Gallet que anticipa esta inserción de la música, sea ella convencional o electrónica (p. 812).

La proximidad con el teatro urde una posibilidad de análisis de la estructura musical sugestiva y coherente que propuso Luis Rivero, músico mexicano.

Nuevamente la energia es la que hace variar las estructuras existentes. Esta interacción que funciona en el desarrollo melódico en un tiempo da razones para ver aparecer la conmutación y la preeminencia de la forma como el sentido de la obra.

La música del compositor Rivero asimila la tradición alemana y reitera en el espectador mexicano una creación que ingresa a la sala como a un lugar conocido que a la vez toca la frontera que habia señàlado la actuación.

Música y continuidad melódicas no se encuadran en la percepción. El sonido se capta en el instante pues el presente es su forma. La idea de circulación de los sonidos induce a una cierta concepción musical. Porque el espectador recibe un estallido de sonidos que se acompaña con el balanceo del director de orquesta. La oreja se confronta con la dispersión y las estructuras convencionales que esperamos que aparezcan no resisten lo aleatorio de cada instante. Lo aleatorio substituye el despliegue pseudo orgánico de la forma.

La tradición musical puede darnos la impresión de mantenerse aparte de este ensanchamiento de 
nuestro universo sonoro. Peter Brook dice que de esta manera se eleva el nivel de energia en las formas teatrales.

La experiencia del espectador resuelve en unidad la aparición de la música y de los integrantes y sigue una pista que organiza la cualidad sensorial del espectáculo.

En la sala la música es una compacta migración de ruidos, sonidos, que salen expulsados y producen una transformación permanente en los oidos. Parece a veces una deformación de la música, no una repetición. Damos lugar a la exploración o intromisión que rompe el texto que se oye. Esta intromisión parece irrumpir en el entorno con una canción que arrastra temas muy conocidos y revive climas y se acompaña de las posturas de los músicos de la Orquesta de la Marina Nacional.

Resulta un hallazgo la orquesta en el espectáculo. Cada instrumento, particularmente el bombo tiene una dimensión invasora que acompaña a los cantos, gritos, aullidos, desplazamientos físicos, ruptura o quiebra del silencio.

En cada momento de la obra aparece un colorido renovado $\mathrm{y}$ alguien puede hallar los textos que necesita para completar ese andamiaje musical que refuerza a la cultura que se declara como argumento del siglo.

Pienso en la guerra y la paz que atraviesa el espectáculo desde el inicio hasta el final.

Siendo asi la propuesta musical resulta ser una estructura del espectáculo pensada e instalada sin continuidad y sin ruptura, porque tiene una manera de aparecer y darse a conocer que el espectador 
puede invocar y a la vez transgredir si se lo propone.

Señalo con insistencia que como espectadora no se puede describir una situación ideal porque en cada momento uno se siente afectado. El espectáculo se reparte, se parte y se comparte en todas las partes del espacio escénico.

No se trata de separar lo que se distingue. Lo que se ve y se oye o se cree ver y oir, entre lo que "aparece" y lo que "debe aparecer" que fueron necesidades, o baluartes de la semiótica tradicional en su afán por dar respuesta a un análisis que desmembraba al espectáculo.

"No se trata de resolver, sino de disolver" dice Veronese, los espacios que conocemos, porque los espectadores ambicionan justamente destruir la pobre imagen de un ser singular recorriendo los espacios asignados por la imaginación de un escenógrafo.

Se solicita ver el entramado de una semiótica del espacio escénico asomando en los espectadores.

Para lo cual hace falta trocar la forma única ambivalente, plurivalente, para fomentar e incentivar el encuentro con signos dramatúrgicos no reconocibles en las zonas de oscuridad o misterio porque lo que tiene primacia es el encadenamiento entre los objetos y los actores.

A veces el espectador no se detiene a sentir que objetos y actores se van descubriendo mutuamente. Descubrir que algo conocido ha dejado de serlo porque tiene una función propia en el espectáculo como sucede con las reses del Pierpont Mauler, con las frases hechas del estafador, los corrillos de los 
obreros que claman por no tener trabajo mientras sostienen un plato de sopa vacio y son estos objetos lo que orquesta o abruma al espectador. Que a la vez salta por encima de tales significados para producir esa sintesis que reclama su historia personal. Ya que cada uno de esos elementos no están en el destino de la obra sino en la propuesta de trabajo del director para provocar una significación que cada espectador repite $u$ desentraña según su modo de ver.

Cuando Peter Brook se refiere al "teatro mortal" en el Espacio vacio espera ese salto del espectador que le autoriza una versión diferente para cada uno.

El espectador actual es diferente al espectador tradicional que estaba fijado a la silla sin más horizonte que trasladar lo que "sucedia" a su vida personal.

Sucede, y es la experiencia con Santa Juana de los Mataderos, que el espectador tuvo el sentimiento de lo esperado y tambien de lo rechazado.

La participación del espectador lo salva del "teatro mortal" del aburrimiento que sabotea la expectativa privada.

Dejemos entrar la noción de tiempo. Sabemos algo de todo pero lo que pasa hoy hay que averiguarlo, porque lo ignoramos. Es un saber que no se sabe, lo llaman el saber del inconsciente.

Pero asi como ingresamos o ingresa esta dimensión significativa al sujeto, con el mismo impulso choca y se estrella con una concepción ya adquirida que tiene su dinámica. Esto quiere decir romper. En todo momento del trabajo creativo el sujeto, sea actor, director, espectador, está traicionando lo aceptado en virtud de la sorpresa que 
le provoca tal experiencia.

$\mathrm{El}$ propósito de desarrollar las sugerencias de un espectáculo sobre el cual establecer lineas de trabajo que sirvan para pensar en una semiótica del espectáculo requiere presentar un "momento" de uno de ellos que hemos seleccionado entre los de la cartelera de la ciudad de México a finales del año 2000 , con el que se elabora esta investigación.

Las características del espectáculo, ya señalado van a mostrarse en una escena que es "significativa" del sentido general de la obra. No es necesario elaborar o pretender analizar un espectáculo integro. Es justamente la selección de un momento o una escena lo que puede cumplir con el objetivo de este libro.

Lo que a la vez indica una marca metodológica. El discurso integro no es el material, sino la selección lo que aporta las dos vertientes. Una el por qué de tal selección y otra, la descripción de lo elegido como impacto en el espectador.

Seguramente no es un consejo para los críticos de espectáculos, pero sería una condición "higiénica" para contribuir a la elucidación y producción de las propuestas semióticas.

La escena que se reproduce figura en el guión de la obra, es decir que es un texto de la dramaturgia de autor al cual se añaden las acotaciones del director.

La selección tiene en cuenta el momento medio del desarrollo del espectáculo que, más que ningún otro, representa la unidad temática y crítica que interesa para un análisis de un todo. No es una sintesis, sino lo significativo del relato brechtiano que 
se ocupó de destacar un momento de emergencia. Para analizar hay que escuchar a las partes y éstas estân representadas en una coyuntura que emerge sin ánimo de conciliación.

No es un final feliz, ni una reiteración de los principios de solidaridad social, ni de resumen anecdótico. Ha sido necesaria una etapa de reflexión para poder elegir lo que ya no era la obra del autor sino lo que para quien hace el estudio configura lo que puede destacarse de una historia.

La dirección del espectáculo enfatizó en ocasiones circunstancias que en este análisis no se consideran. Cada sujeto recoge las marcas que reconoce ligadas a la historia personal y por ello figura la diferencia. Es una señal de transparencia atender tales marcas, no desdeñarlas, no soslayarlas para no recaer en reiteraciones, olvidos y negaciones.

$\mathrm{El}$ análisis semiótico es selectivo en varios niveles del análisis. No se trata de hacer un ejercicio didáctico e intentar más clasificaciones porque en cada ocasión el análisis se desplegará según sus necesidades.

La escena escogida es una breve unidad de anălisis.

Las mujeres que son victimas de atropello y que no lo saben se repiten en la obra de Bertold Brecht. Es conocida la historia de Madre Coraje que transporta un carromato con sus hijos en época de guerra.

En Santa Juana de los Mataderos se trata de la señora Niddle, esposa de Lucas que propongo como eje del conflicto.....

"SLIFT" (asistente de Mauler)(dice) Hace cuatro 
dias el viejo Lucas que controlaba la palanca de acceso de la carne en la gran boca de la trituradora, se distrajo por un pensamiento que ya no pudo contarle a nadie..." (Libreto página 43).

Las notas del libreto informan que: Lucas rema, deja el remo, jala la palanca, para la máquina, rema jala la palanca. De pronto en un intervalo de su mecánica (jala la palanca, para la máquina, rema, jala la palanca) saca un papel de su bolsillo, se descoordina, se le cae el papel dentro del embudo, al ir por él, empuja la palanca con su cuerpo, al intentar detenerla, se resbala y cae dentro dando un horrible alarido".

La escena siguiente aparece un joven designado por SLIFT para reemplazar a Lucas. El joven canta;

Pobre Lucas Niddle

Regresó al mundo

Hecho tocino

El tio tocino vestido de lata

SLIFT (escucha la canción y dice al joven)

A la hora del almuerzo vas a ir al comedor 7 , buscas a la señora Niddle, la esposa de Lucas, que estará ahi preguntando alguna razón sobre el paradero de su marido. Te le paras enfrente y sin más le dices de dónde sacaste la chamarra y la gorra (que pertenecian a Lucas Niddle).

(El joven contesta)

-No licenciado, por favor, no puedo hacer eso - ¿Por qué? 
- Está muy cabrón.

- Bueno si un poco, si no tuvieras tanta necesidad.

- Está bien, como usted diga. Puede confiar en mí licenciado.

Se cierra este diälogo determinante de la situación grotesca.

A continuación es la señora Niddle que aparece a la puerta de la fábrica y golpea, cuando se abre una pequeña ventana, la señora Niddle grita:

- Soy yo otra vez y no me voy a ir hasta que me digan qué hicieron con mi marido allá adentro. Llevo cuatro dias aqui parada y mi marido no sale. Pregunto y pregunto. Nadie me dice nada. Pero yo si les digo que aqui me voy a estar, aunque me pudra de frio hasta que salga

¡Ay de ustedes si le hicieron algo!

SLIFT. -su marido está de viaje señora Niddle.

NIDDLE. -¿Qué que dice? ¿Qué viaje?

SLIFT -Asi es señora, de viaje. Y sepa... que también para esta empresa resulta muy inconveniente que permanezca usted aqui diciendo tonterias. Asi que para bien de todos, me voy a atrever a hacerle una oferta generosa. Si usted renuncia a sus molestas pesquisas, podrá comer gratis en nuestro comedor tres semanas.

NIDDLE- ¿Comer gratis? Primero digame qué le pasó a mi marido.

SLIFT- Ya le dije, está de viaje. Uñ viaje a Los Angeles.

NIDDLE- ¿A Los Angeles? 
SLIFT-Si a Los Angeles.

NIDDLE - Eso no es cierto. No mienta, ¿Qué pasó? ¿Por qué lo esconde?

SLIFT- Si insiste señora... Si lo prefiere contrate a un abogado e inicie un litigio. Pero yo que usted lo pensaba dos veces... La espero en el comedor 7 a la hora del almuerzo... Con permiso (cierra la puerta).

NIDDLE.- Espere. No. Tiene que oirme. Abra. Necesito a mi marido.

Tiene que oírme. No tengo a nadie más.

El viento empieza a soplar de nuevo y arrastra papeles y basura. La anciana abatida deja de golpear la puerta. Mira hacia la calle por donde crece amenazante el viento.

NIDDLE. Qué va a ser de mí. Dios mío.

Con esta escena se cierra la propuesta de este análisis, cuando el rostro de la señora NIDDLE está oculto.

El asunto de la significación que está en el título del libro se refiere a la posibilidad de entender que esta escena, párrafo o segmento está entrecruzada en la construcción que es a la vez una demolición, porque es el espectador el que siente el miedo, que es la emoción ante lo desconocido, como una demolición de lo que está antes en la escena.

En este momento el encuentro de los personajes determina una crisis de sentimientos que propicia rupturas porque por una parte los dueños del trabajo 
no saben que Lucas es un ser humano, es decir algo diferente a lo que produce en el lugar al que lo destinaron. Además Lucas tiene una mujer que lo reclama que reclama a su marido. El encuentro de ambas situaciones está cerrado en la caracterización fija o determinada que los dueños de la fábrica no conocen.

El capataz y Lucas ocupan el mismo espacio, que es la fábrica. Sus funciones difieren y ninguno conoce al otro. Sin embargo hay una dependencia que los aniquila como sujetos. Y los destruye asi mismos porque son miembros de una maquinaria de la que no poseen el control.

Las canciones que al estilo de Brecht, como en el coro griego relatan lo que le ha ocurrido a Lucas enlazan la escena al nivel de una guerra despiadada sin vencedores ni vencidos.

Las marcas que conocemos de ambos contendientes reflejan una estructura social que los condena a continuar en una dirección sin salida. Pero los objetos señalan otras lineas de acción y de emoción: las ropas de Lucas, dejadas antes de comenzar el trabajo invocan las voces de su mujer y la de los compañeros que ridiculizan el destino de Lucas pero que a la vez se erigen como el propio destino, el que los espera a pesar de que siguen vivos.

"Lucas es ahora tocino en lata".

Peter Brook utiliza una frase para despejar las confusiones significativas sobre la verosimilitud del personaje de Brecht "Madre Coraje", 
"Hay que inventar los signos de la usura"

¿Cuả es el signo o los signos de la Sra. Niddle?

No son su cuerpo encorvado, ni su cabeza cubierta por un chal, ni su voz o su grito. ¿Qué es entonces? La pregunta y la insistencia tozuda que nadie contesta, porque la respuesta que recibe no le llega al cerebro, sino a la altura del sentimiento de dolor.

Cuando el reemplazante de Lucas amaga sobre la crueldad de lo que le propone el capataz, tal es anunciar a la Sra. Niddle la muerte de Lucas, porque êl estã usando sus ropas, la trama entra en otro clima que parece la pseudo realidad de la fábrica.

Usar los objetos de Lucas, es la muerte, aceptar la muerte en el lugar del trabajo. Pero aún más cede a la Sra. Niddle que ocupa el lugar de otra muerte que es la de ella y la de todos.

El lugar de la comida ha sido en el transcurso de la obra la señal de la destrucción. Es una comida "que no se merecen", es una comida "que enmienda la horfandad de la Sra Niddle. Es finalmente una pobre comida que no cumple la función de saciar el hambre. Los objetos para la comida permiten al espectador la fantasia de una salida airosa de ese macabro mundo de venganza. Comer es vivir y es a la vez tener un lugar que los demás reconocen. Pero lo que podria llevar a un desenlace reñido y desafiante quedan nuevamente en la penumbra por la aparición del "Ejército de Salvación".

El recurso al "Ejército de Salvación" el "dador" de la comida con la finalidad de guiar a los obreros a la salvación reafirma el clima de entrega que padecen 
estos hombres y mujeres que claman por tener su lugar en la sociedad.

Los espacios de la obra se reducen a las acciones de los obreros que confrontan la grandiosidad de la fábrica en relación con su lugar inexistente.

Cada objeto, cada hombre, cada silencio pertenece a la fábrica. Ellos ya saben cómo entrar y salir de cada rincón cuando son llamados por la voz del dueño.

La advertencia de Slift "... inicie un litigio. Pero yo que Usted lo pensaba dos veces", indican nuevamente el espacio exterior al que a ella, la señora Niddle, le está prohibido entrar.

Cuando los objetos cobran relevancia los sujetos parecen desaparecer porque sucede un diálogo en el que unos dominan a otros.

Los icones del "Ejército de salvación", los platos vacios, las ropas, las puertas cerradas y las ventanas apenas entreabiertas, las voces altisonantes para que rompan el aire y entumezcan los cuerpos ya de por sî helados son algunas de las señales que se reparten en la escena.

El derecho sobre cada lugar es el derecho de matar que la sociedad anuncia en este momento de la obra. Esta objetividad es al mismo tiempo el grado de la subjetividad que no se ha desarrollado sino que ha sido determinada por las acciones de los otros. Los obreros está determinados.

Las idas y vueltas a las que se ve sometida la Sra. Niddle que desconoce el destino de su marido definen una circularidad o repetición para demostrar la inutilidad de cada acción que se encadena a la siguiente, sin posibilidad de modificación. 
La caracteristica de las acciones pone a este momento entre los más álgidos porque no se encaminan a ningún lado y tampoco de desplazan, sino que los vemos detenidos, por lo cual en todo momento se experimenta la emoción de la muerte, aunque los personajes no parecen saberlo.

Los espectadores no podemos esperar nada, salvo saltar por encima de las negativas y de la muerte para anunciar que hay otro modo de vivir.

Lo que significa que hay otra cultura que es posible descubrir cuando se agota el movimiento de una repetición imposible de detectar.

Desde fuera del circulo es posible ver al circulo.

La esperanza de salir de tal círculo está ceñida a la resistencia de la Señora Niddle que sabe lo que quiere y lo dice "Necesito a mi marido" "Tiene que oirme" "No tengo a nadie más".

No parece que ella ha cedido a las mentiras. Sabe de qué se trata. Porque ha sido el temor con el que vivian y con el que viven, tal es que una minima distracción arrastra al obrero a seguir la suerte de los cerdos.

Pero asi mismo es un saber que no se sabe. La muerte está presente pero está siempre más lejos, en los demás, es lo que la Sra. Niddle defiende. No es Lucas el que ha muerto.

"¿Por qué lo esconde?" Aparece el juego de la vida cotidiana. No tenemos nada porque alguien que lo tiene lo oculta. Pero un dia lo tendremos todos parece decir la pregunta de la Sra. Niddle.

Este juego de verdad y mentira como relatan los prisioneros de los campos de concentración es el área que los que están fuera del campo desconocen. 
La Sra. Niddle crece en la medida en que penetra en los silencios y reclama, y acepta la comida como personaje del juego que le hacen jugar. Ella seguirá viviendo porque tiene el lugar de su voz.

La explicación de un viaje a Los Angeles sirve al espectador como una luz que descubre lo grotesco pero a la vez lo imposible porque puede ser el instrumento para cubrir la mentira y hacerla visible. La hace tan visible que produce tanto dolor como los objetos que se manipulan durante la escena del ingreso del reemplazante.

La Sra. Niddle tiene más apariciones durante la obra, ella está del lado de los compañeros de su marido y comparte llanto y risas como le sucedia a La Madre de Gorki. Su ingreso a la lucha por el trabajo fortalece el lugar que ella habia ganado en su reclamación.

"Carne que empaca carne" es la parábola de la explotación que se resuelve en autoexplotación que se desconoce porque la distracción que lleva a Lucas a caer a la trituradora carga con la imagen de "un pensamiento que ya no pudo contarle a nadie".

Como la caída del papel que intentó detener es lo que provocó que él resbalara, el papel era probablemente algún discurso político que temia que alguien encontrara. Fue entonces el discurso en primer lugar el que gana el lugar de detonador para que se dispare la contradicción.

Las palabras: papel, trituradora y la propia vida dicen al espectador relaciones que también están articuladas sin dificultad en cualquier otro texto de la vida cotidiana.

Asimismo "Carne que empaca carne" circunscribe 
la identidad del sujeto-carne que trabaja y puede el espectador conmutar los nombres para certificar otras relaciones válidas y pertinentes. "Dolor que trae dolor".

"El tio tocino vestido de lata". Para descodificar esta imagen del cuerpo no como una intervención explicativa sino como una palabra introducida en el código de la imagen inconsciente del cuerpo. Vestido de lata indica el estuche nuevo, adquirido sin trámite, como hecho a propósito y con buen resultado.

La imagen reproduce la monstruosidad de los múltiples genocidios que reducen el cuerpo a una imagen inconsciente.

Entonces no se trata de leer en el sentido de la interpretación, sino de hablar inconscientemente a través de mi imagen del cuerpo el mismo código implícito en el cuerpo.

Asimismo la intervención del capataz para que el obrero ocupe el lugar de Lucas destaca el momento de asimilación de ambos: el capataz y el obrero cuando dice

"si no tuvieras tanta necesidad"

Palabras que está indicadas en el gesto del obrero que se acerca y se separa de la ropa de Lucas. La "necesidad" de él no es la "necesidad" del capataz.

Por lo cual hay alli un traslape de significados que redunda en una confusión de intenciones.

No se sabe cuál es la necesidad del capataz pero sí hay un orden como finalidad sin reparar en los medios.

Los movimientos escénicos mantienen la unidad 
con luces y colores y sonidos que están impregnados de la materia del espectáculo. El espectador no distingue la palabra de los sonidos sean ellos musicales o vocalizados porque no se trata de la narración, ni del discurso, sino de su sentirse afectado por el todo en el que participó. Quiero decir, que distinguir isotopias, musicales o verbales continua siendo ocioso. El espectador, cada espectador dirá, si se atreve, algo particular que corresponde a su manera de recibir el impacto de un mundo que lo ha despertado a otro mundo que tenia guardado u olvidado.

Si no hay narración para contar, no hay argumentación para discernir, actores y objetos se modifican, se envuelven y penetran con las armas que el sujeto espectador puede esgrimir.

Por otra parte la obra no espera al espectador, no hay duplicación de niveles, o estados o modos de aparecer. El sujeto espectador es el múltiple acertijo que cada uno aspira o puede manipular. Lo que se requiere para entrar a una nueva mirada del espectáculo es precisamente la no separación, no quiere decir la no disgresión, porque todo sucede en el cuerpo del espectador. Reconocer la dimensión de este nuevo espectador es lo que se propone la semiótica de la significación.

La separación propone unir, y la unión es conflictiva ¿Para qué una propuesta que debe ser corregida a poco de ser formulada? La visión unitaria es la del sujeto espectador, no se trata de una postulación estética, moral o espiritual sino de reencontrarse como sujeto en el lugar en el que se está.

Las duplicaciones que generan la variedad de los 
espectáculos entre "ellos" y nosotros", concurren a la tradicional visión del arte como exógeno, exterior, rescatable.

Es verdad que hay espectáculos que nos "rechazan", nos "evitan" y es la prueba de la diversidad de nuestra intima problemática, referirse a las experiencias que nos estremecen es el objetivo de una significación que genera nuevas formas de vida en el lugar que nos corresponde. 


\section{Epilogando}

Advierto que el objetivo que persigue este trabajo es reunir las vertientes que articula un espectáculo teatral, vertientes que se suceden y se intercalan para dar razón del acontecimiento, la catástrofe que representa la significación en el espacio escénico. Las vertientes procuran la aproximación a la semiótica del espacio escénico que es el objeto de la investigación en el afán de abrir los caminos cerrados en la semiótica tradicional empecinados en permanecer en el área de la puesta en escena y el acoplamiento de las dramaturgias que enrolan al actor, la actriz, el sonido, la escenografia, etc. Revisitadas por las nuevas tecnologias y las propuestas "alternativas".

Cada espectáculo tiene una lógica de combinación irreductible a los códigos que se convierten en mero material que debe ser reagrupado según las variaciones perceptivas y pueden albergar sistemas de relaciones abstractas y formales. Si la imagen es concreta, las relaciones de montaje forman redes inteligibles.

La experiencia de la participación del espectador configura un lugar en el espacio escénico que se traduce en la significación del espectáculo. Para llegar 
a ella se requiere atender las observaciones, reflexiones e invocaciones que el sujeto espectador reclama como centro de la semiótica que se renueva. No hay un término o punto final en la significación lograda, porque cada espectáculo y cada espectador tienen recursos, historias que deben ser atendidas.

No hay un cuadro de signos que sea lo suficientemente exhaustivo, porque el lenguaje, el espacio, la geometria, el inconsciente juegan o participan de manera singular con cada nuevo objeto.

Así como una investigación requiere de un método afin al objeto para no caer en la llamada "ilustración" del método, de la misma manera el estudio de un espectáculo requiere la asistencia de las fuerzas que conmueven y trastocan la mirada convencional del espectador.

Sin duda es un apuesta a la inserción del espectáculo teatral al área de las ciencias humanas y sociales, asi como Saussure desafió a los lingüistas proponiendo una ciencia que aún no desarrollada introducia a la lingüistica en una campo definido por el sello de la investigación científico-social y la llamó semiología.

Los continuadores dieron variadas señales del desarrollo de la semiologia/semiótica pero consideraron que observar las señales de tránsito era el punto final de esa aventura y declararon el acta de defunción de la ciencia citada.

Que fracase la memoria, donde la memoria no habia fracasado para no volver a ver lo mismo sino reveer que es la manera de mirar que complementa la frontalidad a la que estamos habituados.

Quiero decir que hay que atender lo cambiante, 
lo que no corresponde a lo conocido lo que no nos da la razón. Por ello se trata de reveer.

Cada nivel de mutación de los objetos envuelve al anterior y es un nuevo sistema de comunicación.

Hay dos lectores uno que consume la anécdota de página en página y otro que es el lector simbólico que se pregunta a sî mismo, es la nota del ingreso al inconsciente, el tiempo no es un antes ni un después es reversible.

La significación permite $u$ ofrece una condiciōn que es la critica para descifrar, traducir, no interpretar.

Convengamos que se trata de otra manera de pensar -reformas del entendimiento- que no sólo el espectáculo teatral está proponiendo, sino que se da en la investigación científica de la biología, la medicina, las matemáticas, el cine, en un sinfin de actividades que el sujeto emprende cuando no se siente reconocido en los discursos atemporales e históricos, moralizantes o artisticos. 

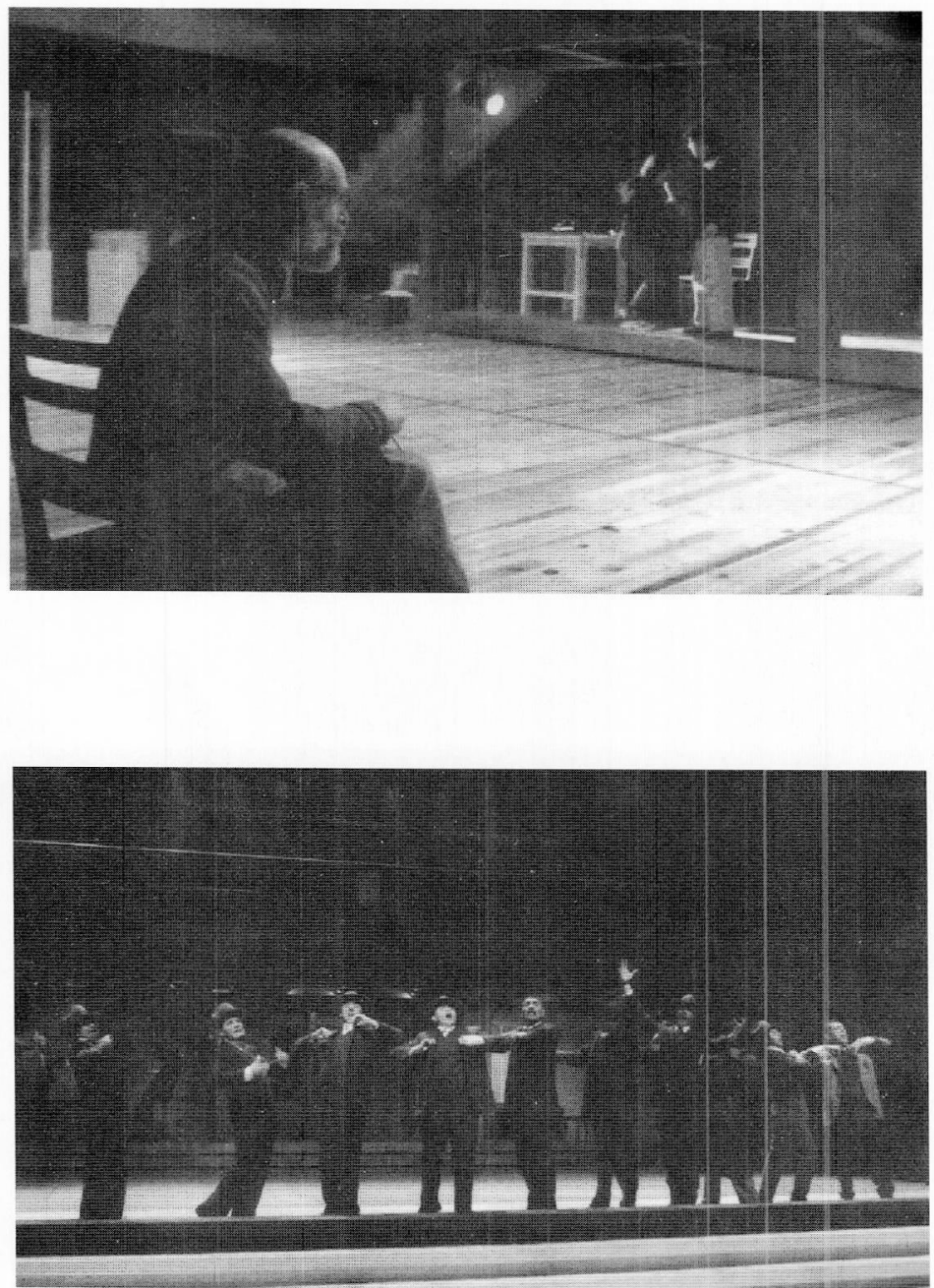

Là fotografias que reproducimos pertenecen a José Jorge Carreón y fueron tomadas del programa de mano editado por CONACULTA/INBA 


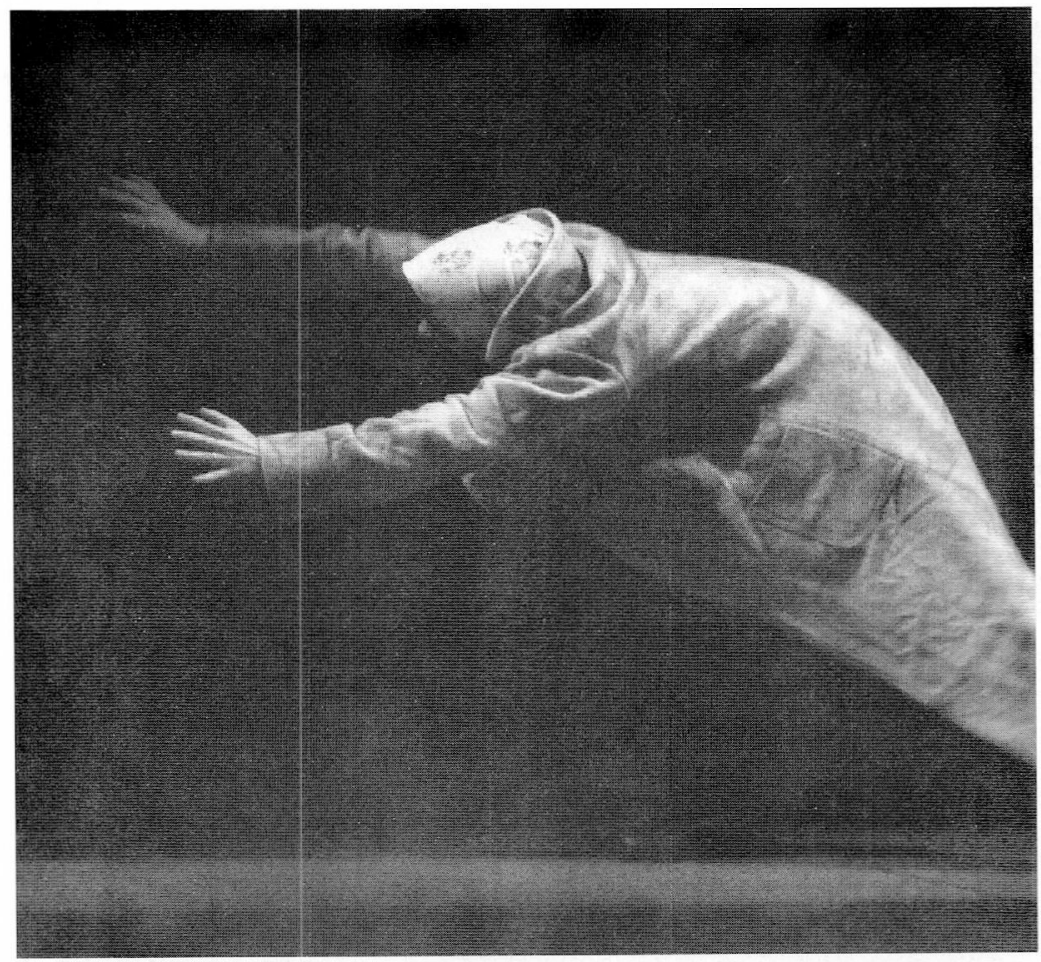



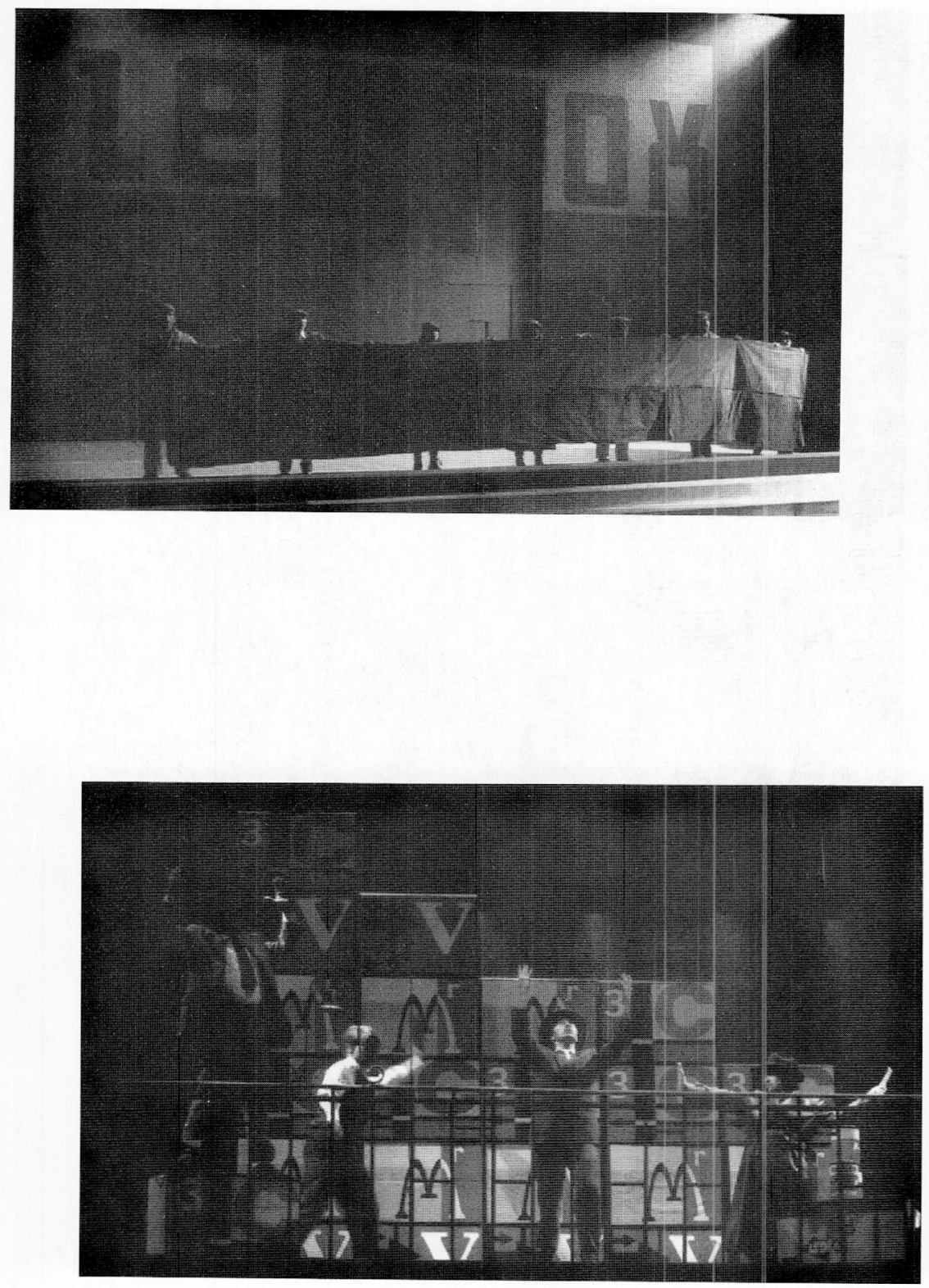


$$
\text { I }
$$




\section{Bibliografia}

Adorno, Theodor $\mathrm{W} .$, Philosophie de la nouvelle musique, Paris, 1962, (1958).

Alegria, J., et all, L'espace et le temps aujourd' hui, Ed duSeuil, Paris, 1983.

Barthes Roland, Lo obvio y lo obtuso. Imágenes, gestos, voces, Piados, España, 1995 (1982).

—, El grado cero de la escritura, Siglo XXI, México, 1976.

—, L'aventure sémiologique, Editions du Seuil, Paris, 1985.

—, Le grain de la voix, Editions du Seuil, Paris, 1981.

Bausch, Pina, Histories de théâtre dansé, L'Arche, Paris, 1987.

Brecht, Bertold, Santa Juana de los Mataderos, versión libre realizada por Eduardo Weiss, Stefanie Weiss, Antonio Zuñniga y Luis de Tavira, México, 2000. 
Brook, Peter, El espacio vacio, México 1978.

--, Le diable c'est l' ennui, Cahiers $\mathrm{N}^{\circ} 4$, Actes du Sud, Paris, 1991.

Bruner, J.S., "Les processus de préparation a la perception" en Logique et perceptionVI, Bibliotheque scientifique internationale, PUF, Paris, 1958.

Cahiers Art et Science, Revue annuelle, Université de Bordeaux, Paris, 2000.

Damisch Hubert, L'origine de la perspective, Flammarion, Paris, 1987, 1993.

Degres, Revue de synthese á orientation sémiologique, Année 27, $\mathrm{N}^{\circ} 97,98,99$, Bruxelles, Belgique.

Denis Michel, Image et cognition, PUF, Paris, 1994.

Despins, Jean-Paul, La música y el cerebro, Gedisa, Barcelona, 2001.

Desesquelles, Anne Claire, "Forme et énergie dan la musique", en Critique, Tome LVI, $\mathrm{N}^{\circ}$ 639-640, Paris, août-septembre 2000, pp. 728-742.

Ducrot Oswald, Schaeffer Jean-Marie, Nouveau Dictionnaire encyclopedique des sciences du langage, editions du Seuil, Paris 1995, (ver Hjelmslev).

Eco Humberto, Tratado de semiologia, México, 1978. 
Ecole Supérieur, des Beaux Arts, La video entre art et communication, Paris, 1997.

Encyclopedie Universelle, Paris, 1998. (ver: Expérience, Gregory R, Peackoque, Christopher, Wittgenstein).

Granon-Lafont Jeanne, La topologia de Jacques Lacan, Nueva Visión, Buenos Aires, 1999.

Goldmann, Nelson, L'art en théorie et en action, Ed. L"êclat, Paris, 1996, (1984).

Hjelmslev, Louis, Nouveaux Essais, PUF, Francia, 1985. Introduction de Francois Rastier.

Husserl, Etudes phénomenologiques, Tome XIV, $\mathrm{N}^{\circ}$ 2-28, editions Peeters, Belgique, 1998.

Imbert, Claude, Pour une histoire de la logique, PUF, Paris, 1999.

Joly Martine, $L$ image et les signes, Nathan, Paris, 1994.

Julien, Philien, Pour lire Jacques Lacan, E.P.E.L., Paris 1990.

Lacan Jacques, Seminario 2, 3 y 20, Paidos, Buenos Aires, 1975.

Laplanche, Jean, $L^{\prime}$ inconscient et le ca, PUF, Paris, 1981. 
Lecoq, Jaques, Le corps poétique, Actes SudPapiers, Paris, 1997.

Les Cahiers de les sciences de l'art en questions, Montreal, 2000, L' Harmattan.

Lorenz Konrad, Sobre la agresión: el pretendido mal, Siglo XXI, México (1963), 1998.

Lotman Juri/Uspenski Boris, Richerche semiotiche, Einaudi, Turin (I) 1973.

Lotman Juri, La semiosfera III, Semiótica de las artes y la cultura, Edición Desiderio Navarro, Universitat de Valencia, Ed. Cátedra, España, 2000

Mannoni Octave, Freud el descubrimiento del inconsciente, Ediciones Nueva Visión, Paris, 1987.

Meyerhold, Textos teóricos, Edición de Juan Antonio Hormigón, Publicaciones de la Asociación de Directores de escena de España, España, 1998.

Millet, Catherine, $L^{\prime}$ art contemporaine, Flammarion, Paris, 1997.

Murakarovsky, Jan, Escritos de Estética $y$ semiótica del arte, Ed. Gustavo Gilli S.A., España, 1977, (1975).

Paquin, Nicole, Le corps jugé. Sciences de la cognitionet esthétiquedes arts visuel, Col. PUV, Québec, 1993. 
Parret, Herman, L'esthétique de la communication, Eds Ousia, Grecia, 1999.

Poissant, Louise, Esthétique des arts médiatiques, P.U. de Quebec, 1998.

Proust, Joëlle, L' interdisciplinarité dans les sciences cognitives, Rapport $\mathrm{N}^{\circ} 9030$ B Décembre CREA (Centre de recherches), Paris, 1990.

Puech, Christian, en Langages, 92/107, Sémiologie et histoire des theories du langage, Larousse, Paris.

Rastier, Francois, Arts et sciences du texte, PUF, Paris, 2001.

-, "problemes du signe et du texte" en Intellectica $1996 / 2 n^{\circ} 23$. Paris, Revue de l' association pour la recherche cognitive".

- "L "Laction et le sens" en Journal des anthropologues $\mathrm{N}^{\circ} 85-86$, mai 2001, Paris, p. 183219.

-, et Simon Bouquet -Une Introduction aux sciences de la culture, PUF, Paris 2002,

Schaeffer, J.M., Adieu a l'esthétique, PUF, Paris, 2000.

Shepard, Roger N., L'oeil qui pense, Editions du Seuil, Paris, 1992. 
Safouan, Mustapha, Angustia, sintoma, inhibición, Ediciones Nueva Visión, Buenos Aires, 1998.

Sebeok, Tomas, Considerazioni sulla semiosi, (traducción presentada en el International Symposium on Semiotics ans Theories of Symbolic Behavior in Eastern Europe end West, impreso por la Brown University, Providence, el 16 de abril de 1976) al italiano de E. Catani y M. Del Ninno, Universidad de Valencia, 1976.

Todorov Tzvetan, Téories du symbole, Editions du Seuil, Paris, 1997.

Veronese Daniel, La deriva, Ed. Adriana Hidalgo, Buenos Aires, 2000. 
El Espacio Escénico. Significación y Medios, editado por la Facultad de Ciencias Politicas y Sociales, UNAM, se terminó de imprimir en octubre del 2003. La composición se hizo en Bookman Old Style 10.5/14.5. La impresión se realizó en papel lustrolito semimate de 100 grs. La edición estuvo a cargo de Comercial de Impresos MB, Petróleos Mexicanos 11, Coyoacán. El tiraje consta de 1,000 ejemplares 


\section{El Espacio Escénico. Significación y Medios}

Es una propuesta para multimedia pues reúne las vertientes que articula un espectáculo teatral que da razón del acontecimiento, la catástrofe que representa la significación en el espacio escénico de sala y escena.

No hay un término o punto final en la significación lograda porque cada espectáculo y cada espectador tienen recursos, historias que reclaman. Quiero decir que hay que atender lo cambiante, lo que no corresponde a lo conocido, lo que no nos da la razón.

Es sin duda la inserción del espectáculo teatral en el área de las Ciencias Humanas y Sociales.

Ana Goutman es doctora en Filosofia por la Facultad de Letras de París, profesora-investigadora en la Facultad de Ciencias Politicas y Sociales y en la Facultad de Filosofia y Letras de la Universidad Nacional Autónoma de México.

Ha publicado: 1985.

Método y métodos. No teorla de los métodos, edición del autor,

Teatro y liberación, Instituto Nacional de Bellas Artes, 1992. Premio Rodolfo Usigli.

Aventuras del sonido, Almagesto, Buenos Aires (A), 1994.

Hacia una teoria de la tragedia, realidad y ficción latinoamericana, CECYDEL. UNAM,1994.

Estudios para una semiótica del espectáculo, UNAM, 1995.

Artesanias lingülsticas-Notaciones sin clave, Siglo XXI, 2000.

Lenguaje y comunicación, Dirección General de Publicaciones y Fomento Editorial, UNAM, 2000.
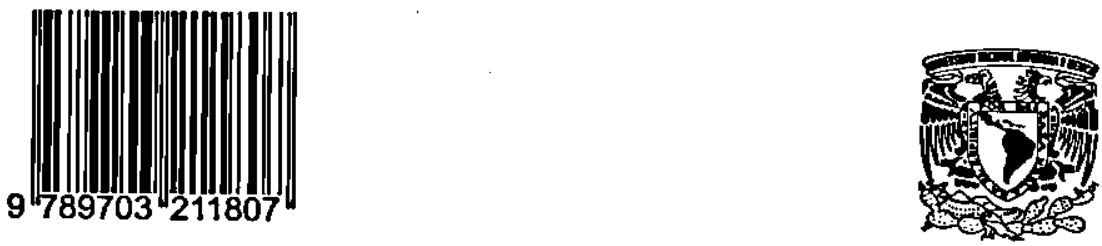